\title{
Modeling Russia for Climate Change Issues
}

\author{
Ali Bayar \\ Frédéric Dramais \\ Cristina Mohora \\ Masudi Opese \\ Bram Smeets
}

\author{
CESIFO WORKING PAPER NO. 2972 \\ CATEGORY 10: ENERGY AND ClimATE ECONOMICS \\ FEBRUARY 2010
}
An electronic version of the paper may be downloaded
- from the SSRN website: Www.SSRN.com
- from the RePEc website: Www.RePEc.org
- from the CESifo website: www.CESifo-group.org/wp




\title{
Modeling Russia for Climate Change Issues
}

\begin{abstract}
This paper presents the dynamic multi-sector general equilibrium model for the Russian Federation (RusMod) and carbon emission projections for Russia up to 2020.

Projection results emphasise the importance of accomplishing strong energy efficiency gains, and their effect on the economy and on emissions of greenhouse gases. However, they also show that emissions can be expected to grow at a much higher rate if the efficiency improvements targeted by the government are not realised or when they stay behind compared to the $40 \%$ goal as it was set by president Medvedev. Model simulations also show that the introduction of a carbon price as a policy instrument can have a strong impact on the emissions, which comes at the expense of a decline in economic growth that is of a much more temporary nature.
\end{abstract}

JEL-Code: C68, Q54.

Ali Bayar

Free University of Brussels and EcoMod

Avenue F. Roosevelt, 50, C.P. 140

Belgium - 1050 Brussels

ali.bayar@ecomod.net

\author{
Frédéric Dramais \\ Free University of Brussels \\ Avenue F. Roosevelt, 50 \\ Belgium - 1050 Brussels \\ fdramais@ulb.ac.be \\ Masudi Opese \\ Free University of Brussels \\ Avenue F. Roosevelt, 50 \\ Belgium - 1050 Brussels \\ Masudi.Opese@ulb.ac.be
}

\author{
Cristina Mohora \\ Free University of Brussels \\ Avenue F. Roosevelt, 50 \\ Belgium - 1050 Brussels \\ maria.c.mohora@ulb.ac.be \\ Bram Smeets \\ EcoMod \\ Belgium - Brussels \\ bram.smeets@ecomod.net
}

Prof. Bayar acknowledges with thanks funding from the European Commission, DG Environment through the research grant 07.0201/2006/448303/SUB/C1. 


\section{INTRODUCTION}

Russia is an important player in international efforts to prevent climate change. Over the last 15 years its share of global CO2 emissions has declined from 11\% in 1990 to about $6.4 \%$ in $2003^{2}$. Despite this sharp decline in GHG emissions, Russia is still one of the world's largest emitters of greenhouse gases, ranking third just behind the United States and China and slightly ahead of Japan and India. Russia holds about 1/3-1/2 of the world's natural gas reserves, has abundant coal (about 20\% of the world reserves) and large crude oil (10\%) resources. Thus, Russian climate policy, combined with its energy and export-import policies, will significantly influence Russia's long-term carbon emissions levels.

Given the complex and dynamic interactions with regard to energy use and GHG emissions, general equilibrium analysis is a relevant framework for GHG projections. In this paper we present the results of a study on the evolution of $\mathrm{CO} 2$ emissions by the Russian Federation over the time span 2008-2020. The projections are based on the dynamic CGE model RusMod.

\section{MODEL SPECIFICATION}

RusMod is a dynamic multi-sector general equilibrium model for the Russian Federation. It models the Russian economy up to 2020 and generates projections for the emissions of green house gases in the same period that are linked to the consumption of energy.

The model is constructed on several building blocks. In the CGE framework, behavioural assumptions are made for every agent in the model, that are fundamental to the outcomes since they will determine how the respective agents are dependent on the decisions of others, or on their results. These assumptions are exposed below, where particular attention is paid to the assumptions made for the different branches of activity in the economy and their production structure, since these are of considerable importance when deriving GHG emissions based on their activity. For the other agents in the model, the comments will be less in-depth; more detailed information can be found in the Technical Report.

The public and private enterprises that are active in Russia's economy are classified in 20 branches of activity (see Table 1). Each branch of activity produces one or several types of goods and services. In total, there are 20 types of commodities, which follow the disaggregation presented in Table 2. Five of the commodities presented in Table 2 represent energy inputs: Electricity, crude oil, refined petroleum and other fuels, natural gas and coal.

2 Calculation based on EIA data (http://www.eia.doe.gov/environment.html) and the Third Russian National communication to UNFCCC (http://www.eia.doe.gov/environment.html). 


\section{Table 1: Branches of activity in RusMod}

\begin{aligned} & \hline 1 Electricity \\ & 2 Crude oil \\ & 3 Refined petroleum and other fuels \\ & 4 Natural gas \\ & 5 Coal \\ & 6 Ferrous metallurgy \\ & 7 Nonferrous metallurgy \\ & 8 Chemical and petrochemical industry \\ & 9 Machinery \\ & 10 Lumber, pulp and paper industry \\ & 11 Construction materials \\ & 12 Light industry \\ & 13 Food processing industry \\ & 14 Other industries \\ & 15 Construction \\ & 16 Agriculture and forestry \\ & 17 Transport and communication \\ & 18 Trade, brokerage and catering \\ & 19 Housing, R\&D and other services \\ & 20 Government and financial services \\ & \hline\end{aligned}

RusMod can be used for detailed impact and scenario analysis at the sectoral level, as well as for forecasting at the sectoral level. It helps its users understand the total macro and sectoral effects of policy decisions. It has the inter-industry detail from input-output, supply and use tables. It allows for behavioural responses to housing and consumer prices, wages, and production costs as in computable general equilibrium models. The model is dynamic, generating forecasts and simulations on an annual basis, and accounting for behavioural responses to wage, price, and other economic factors. 


\section{Table 2: Disaggregation of commodities}

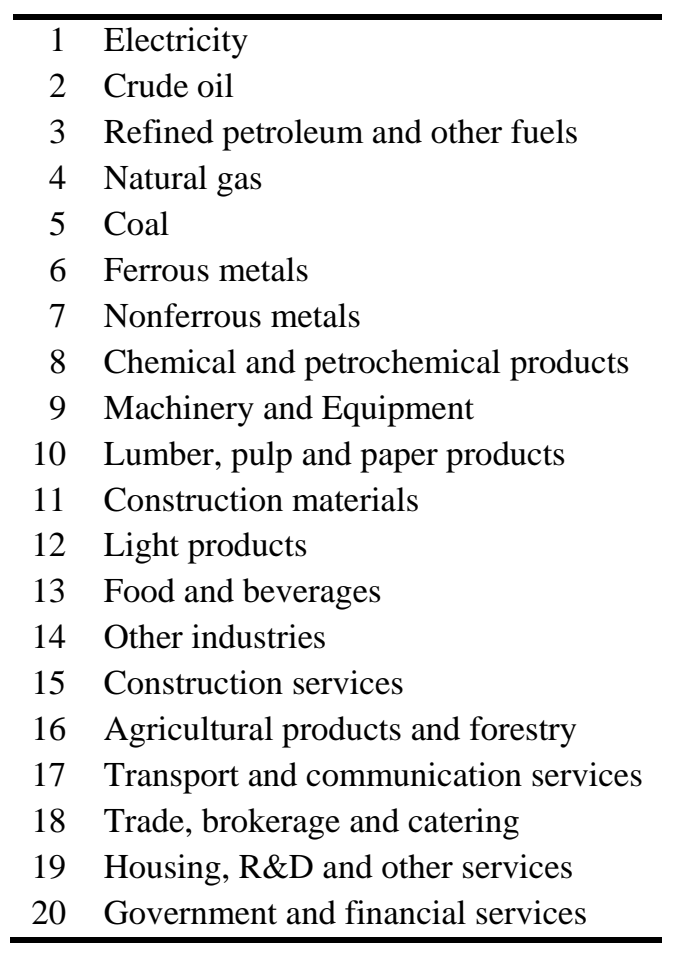

Given the importance of the productive sectors in the GHG emissions, we'll focus below on the technical description of the production structure in the model. Details for the household and the government behaviour, as well as the specification of the trade and capital flows are provided in the technical document of the model.

\subsection{Fims}

The CGE model does not take into account the behaviour of individual firms, but of groups of similar ones aggregated into branches. The model distinguishes 20 perfectly competitive branches of activity (summarized in Table 1).

When developing models in a CGE framework, it is typical to assume that producers operate on perfectly competitive markets and maximize profits (or, equivalently, minimize costs for each level of output) to determine optimal levels of inputs and output. For example, for the firms operating internationally, the world market dictates the output price to a large extent, and hence for an optimal outcome they have to produce as efficiently as possible. Some other firms are constrained in the costs level by domestic competitors. Thus, the optimizing producers minimize their production costs at every output level, given their production technology. Furthermore, production prices equal average and marginal costs, a condition that implies profit maximization for a constant returns to scale technology.

When determining the optimal combination of inputs in order to reach a certain output level, the firms are characterized by their production structure that describes the relation between inputs into the production process and the output resulting from that. For a 
quantitative analysis of these decisions, assumptions need to be made by the modeller on the functional form and structure of the production functions that the firms face. In RusMod, two types of production function are combined in a nested structure. On the one hand, a Leontief function defines fixed proportions of inputs that are required to yield a certain output. On the other hand, the Constant Elasticities of Substitution (CES) production function facilitates more flexibility, to the extent that it allows for substitution possibilities between inputs that are described by substitution elasticities. By combining the two functions in a structure consisting of multiple stages, the necessity to include certain (categories of) inputs and the flexibility to combine or replace others can both be sensibly represented in a nesting structure reflecting these characteristics. Besides, the importance of particular inputs in the production process of certain sectors can be incorporated by adapting the nesting scheme per sector.

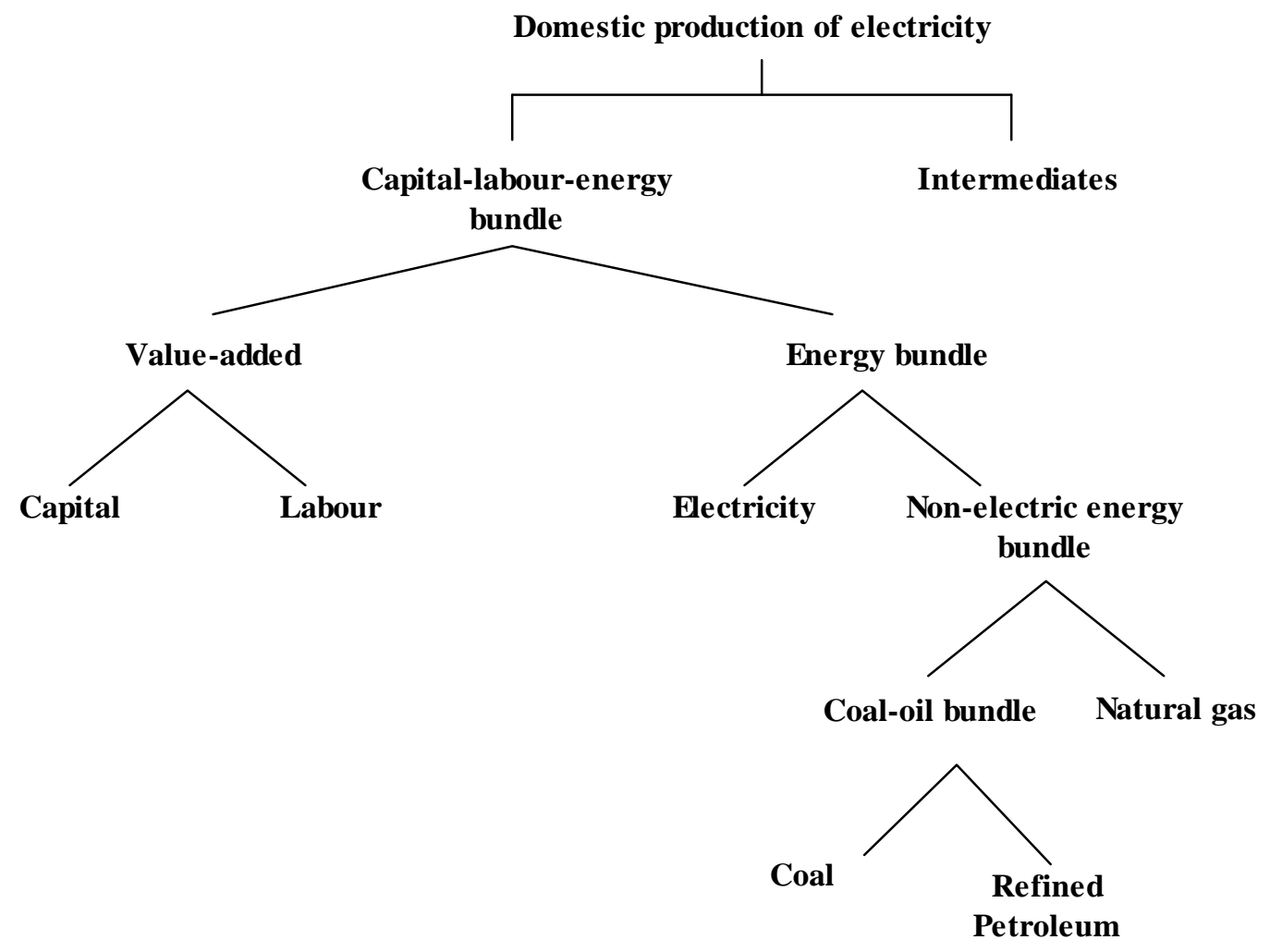

Figure1: The nested Leontief and CES production technology for the domestic production of electricity

For the electricity, gas and steam sector the producers are assumed to choose in the first stage between intermediate inputs and a capital-labour-energy bundle according to a Leontief production function. In the second stage, the optimal mix between value-added and energy is defined by a CES function. In the third stage, value added is given by a CES function of capital and labour while the energy bundle by a CES function of electricity and a non-electric energy bundle. In the fourth stage, the optimal mix between 
natural gas and the coal-oil bundle is given by another optimization process, where substitution possibilities between natural gas and the coal-oil bundle are represented by another CES function. Finally, in the fifth stage the optimal allocation of the coal-oil bundle between different energy inputs is provided by another CES function (see Figure 1). Firms' costs related to corporate income tax and social security contributions are also taken into account in the optimization process.

The domestic production by branch sel $\left(X D_{\text {sel }}\right)$ is defined by a Leontief function with fixed proportions $a K L E_{\text {sel }}$ defining the required input of the capital-labour-energy bundle $\left(K L E_{s e l}\right)$ and, similarly, fixed technical coefficients $i o_{c, s e l}$ defining the required inputs of total intermediate inputs $\left(I_{\text {sel }}\right)$. Then, assuming an optimal allocation of inputs, the demand equations for the capital-labour-energy bundle and the intermediate inputs read:

$K L E_{\text {sel }}=a K L E_{\text {sel }} \cdot X D_{\text {sel }}$

and

$I O_{s e l}=\sum_{c} i o_{c, s e l} \cdot X D_{s e l} \cdot$

Thus, domestic production valued at basic prices net of net taxes, $\left[P D_{\text {sel }} \cdot\left(1-t p_{s e l}\right)\right]$, is given by the sum of the capital-labour-energy bundle $\left(K L E_{s e l}\right)$ for branch sel valued at basic prices $\left(P K L E_{\text {sel }}\right)$ and intermediate commodities used by sector sel valued at the market price of the commodities $\left(P_{c}\right)$, including the trade and transport margins $\left(\sum_{c t m}\right.$ tcictm $\left._{c t m, c} \cdot P_{c t m}\right)$ and taxes $\left(\right.$ tic $\left._{c}\right)$ on intermediate consumption:

$P D_{\text {sel }} \cdot X D_{\text {sel }} \cdot\left(1-t p_{s e l}\right)=\sum_{n e n}\left\{i o_{n e n, s e l} \cdot X D_{s e l} \cdot\left[P_{n e n}+\sum_{c t m} t c i c t m_{c t m, n e n} \cdot P_{c t m}\right] \cdot\left(1+t i c_{n e n}\right)\right\}$

$+P K L E_{\text {sel }} \cdot K L E_{\text {sel }}$

The trade and transport margins are valued at the price $\left(P_{c t m}\right)$ of the corresponding service (wholesale and retail trade services or transport services), while tcictm $_{c t m, c}$ represents the trade and transport services $c t m$ per unit of intermediate consumption of commodity $c$.

The capital-labour-energy bundle is a CES aggregation of value added $\left(K L_{\text {sel }}\right)$ and energy $\left(E N E R_{\text {sel }}\right)$ :

$$
K L E_{\text {sel }}=a K L E N_{\text {sel }} \cdot\left(\gamma K L_{\text {sel }} \cdot K L_{\text {sel }}^{-\rho K L E N_{\text {sel }}}+\gamma E N E R_{\text {sel }} \cdot E N E R_{\text {sel }}^{-\rho K L E N_{\text {sel }}}\right)^{-1 / \rho K L E N_{\text {sel }}}
$$

The corresponding cost function is the sum of the costs related to each input, valued at their respective price indices:

$$
\operatorname{Cost}_{\text {sel }}\left(K L_{\text {sel }}, E N E R_{\text {sel }}\right)=P K L_{\text {sel }} \cdot K L_{\text {sel }}+P E N E R_{\text {sel }} \cdot E N E R_{\text {sel }} \text {. }
$$

Minimization of this function subject to (4) yields the demand equations for value added and energy bundle:

$$
K L_{\text {sel }}=K L E_{\text {sel }} \cdot\left(P K L E_{\text {sel }} / P K L_{\text {sel }}\right)^{\sigma K L E N_{s e l}} \cdot \gamma K L_{\text {sel }}^{\sigma K L E N_{s e l}} \cdot a K L E N_{\text {sel }}^{\left(\sigma L E N_{s e l}-1\right)}
$$


$E N E R_{\text {sel }}=K L E_{\text {sel }} \cdot\left(P K L E_{\text {sel }} / P E N E R_{\text {sel }}\right)^{\sigma K L E N_{s e l}} \cdot \gamma E N E R_{\text {sel }}^{\sigma K L E N_{s e l}} \cdot a K L E N_{\text {sel }}^{\left(\sigma K L E N_{s e l}-1\right)}$

and the associated zero profit condition:

$P K L E_{\text {sel }} \cdot K L E_{\text {sel }}=P E N E R_{\text {sel }} \cdot E N E R_{\text {sel }}+P K L_{\text {sel }} \cdot K L_{\text {sel }}$

where $P E N E R_{\text {sel }}$ gives the price index corresponding to the energy bundle and $P K L_{\text {sel }}$ stands for the price index corresponding to value added. The elasticity of substitution between value added and energy bundle is given by $\sigma K L E N_{\text {sel }}$, where $\sigma K L E N_{\text {sel }}=1 /\left(1+\rho K L E N_{\text {sel }}\right)$, and $\gamma K L_{\text {sel }}$ and $\gamma E N E R_{\text {sel }}$ represent the distribution parameters corresponding to value added and energy bundle, respectively.

Value-added is a CES aggregation of capital $\left(K S K_{\text {sel }}\right)$ and labour, expressed in number of employees $\left(L S K_{\text {sel }}\right)$ :

$K L_{\text {sel }}=a F_{\text {sel }} \cdot\left(\gamma F K_{\text {sel }} \cdot K S K_{\text {sel }}^{-\rho F_{\text {sel }}}+\gamma F L_{\text {sel }} \cdot L S K_{\text {sel }}^{-\rho F_{\text {sel }}}\right)^{-1 / \rho F_{\text {sel }}}$

Minimizing the costs function:

$$
\begin{aligned}
\operatorname{Cost}_{\text {sel }}\left(K S K_{\text {sel }}, L S K_{\text {sel }}\right)= & {\left[P K_{\text {sel }} \cdot\left(1+t k_{\text {sel }}\right)+d_{\text {sel }} \cdot P I_{\text {sel }}\right] \cdot K S K_{\text {sel }}+} \\
& {\left[P L \cdot(1+\text { premLSK sel }) \cdot\left(1+t l_{\text {sel }}\right)\right] \cdot L S K_{\text {sel }} }
\end{aligned}
$$

subject to (9) yields the demand equations for capital and labour:

$$
\begin{aligned}
& K S K_{\text {sel }}=K L_{\text {sel }} \cdot\left\{P K L_{\text {sel }} /\left[P K_{\text {sel }} \cdot\left(1+t k_{\text {sel }}\right)+d_{\text {sel }} \cdot P I_{\text {sel }}\right]\right\}^{\sigma F_{s e l}} \cdot \gamma F K_{\text {sel }}^{\sigma F_{s e l}} \cdot a F_{\text {sel }}^{\left(\sigma F_{s e l}-1\right)} \\
& L S K_{\text {sel }}=K L_{\text {sel }} \cdot\left\{P K L_{\text {sel }} /\left[P L \cdot\left(1+\text { premLSK }_{\text {sel }}\right) \cdot\left(1+t l_{\text {sel }}\right)\right]\right\}^{\sigma F_{\text {sel }}} \cdot \gamma F L_{\text {sel }}^{\sigma F_{\text {sel }}} \cdot a F_{\text {sel }}^{\left(\sigma F_{\text {sel }}-1\right)}
\end{aligned}
$$

and the associated zero profit condition:

$$
\begin{aligned}
& P K L_{\text {sel }} \cdot K L_{\text {sel }}=\left[P K_{\text {sel }} \cdot\left(1+t k_{\text {sel }}\right)+d_{\text {sel }} \cdot P I_{\text {sel }}\right] \cdot K S K_{\text {sel }}+P L \cdot\left(1+\operatorname{premLSK}_{\text {sel }}\right) \cdot \\
& {\left[1+t l_{\text {sel }}\right] \cdot L S K_{\text {sel }}}
\end{aligned}
$$

where $P L$ is the average wage in the domestic employment and $p r e m L S K_{\text {sel }}$ is the wage differential of branch sel with respect to the average wage $P L, t l_{\text {sel }}$ is the social security contributions rate for industry sel , $P K_{\text {sel }}$ is the return to capital in branch $s e l, t k_{\text {sel }}$ is the capital income tax rate for branch sel, and $d_{\text {sel }}$ is the depreciation rate in industry sel. The depreciation related to the private and public capital stock is valued at the price index corresponding to investments by branch of activity sel $\left(P I_{\text {sel }}\right)$. The elasticity of substitution between capital and labour is given by $\sigma F_{\text {sel }}$, where $\sigma F_{\text {sel }}=1 /\left(1+\rho F_{\text {sel }}\right)$, and $\gamma F K_{\text {sel }}$ and $\gamma F L_{\text {sel }}$ represent the distribution parameters corresponding to capital and labour.

At the third nest, the energy bundle is given by another CES function of electricity $\left(E_{N I N P_{\text {enel, sel }}}\right)$ and a non-electric energy bundle $\left(E N E R N E_{\text {sel }}\right)$

$$
\begin{aligned}
& E_{N E R_{\text {sel }}}=a E N E R_{\text {sel }} \cdot\left(\gamma E N E R E L_{\text {enel, sel }} \cdot E_{\text {ENINP }}^{-\rho E N e l, s e l} R_{\text {sel }}+\gamma E N E R N E_{\text {sel }} \cdot\right. \\
& \left.E N E R N E_{\text {sel }}^{-\rho E N E R_{\text {sel }}}\right)^{-1 / \rho E N E R_{\text {sel }}}
\end{aligned}
$$

Minimizing the costs function: 
$\operatorname{Cost}_{\text {sel }}\left(E_{\text {NINP }} P_{\text {enel }, \text { sel }}, E N E R N E_{\text {sel }}\right)=\sum_{\text {enel }}\left\{\left[P_{\text {enel }}+\sum_{c t m} t c i c t m_{c t m, \text { enel }} \cdot P_{c t m}\right] \cdot\right.$

$\left(1+\right.$ tic $\left._{\text {enel }}\right) \cdot$ ENINP $\left._{\text {enel }, \text { sel }}\right\}+$ PENERNE $_{\text {sel }} \cdot$ ENERNE $_{\text {sel }}$

subject to (14) yields the demand equations for electricity and the non-electric energy bundle:

$$
\begin{aligned}
& \operatorname{ENINP}_{\text {enel, sel }}=\operatorname{ENER}_{\text {sel }} \cdot\left\{\operatorname{PENER}_{\text {sel }} /\left\{\left[P_{\text {enel }}+\sum_{c t m} t c i c t m_{c t m, e n e l} \cdot P_{c t m}\right] \cdot\right.\right. \\
& \left.\left.\left(1+t i c_{\text {enel }}\right)\right\}\right\}^{\sigma E N E R_{s e l}} \cdot \gamma E N E R E L_{\text {enel, sel }}^{\sigma E N R_{s e l}} \cdot a E N E R_{\text {sel }}^{\left(\sigma E N E R_{s e l}-1\right)} \\
& \operatorname{ENERNE}_{\text {sel }}=E N E R_{\text {sel }} \cdot\left(P E N E R_{\text {sel }} / P E N E R N E_{\text {sel }}\right)^{\sigma E N E R_{s e l}} \cdot \gamma E N E R N E_{\text {sel }}^{\sigma E N E R_{s e l}} \cdot \\
& a E N E R_{\text {sel }}^{\left(\sigma E N E R_{s e l}-1\right)}
\end{aligned}
$$

and the associated zero profit condition:

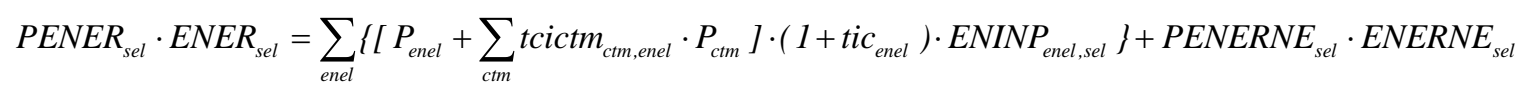

where PENERNE $E_{\text {sel }}$ gives the price index corresponding to the non-electric energy bundle. The elasticity of substitution between electricity and the non-electric energy bundle is given by $\sigma E N E R_{\text {sel }}$, where $\sigma E N E R_{\text {sel }}=1 /\left(1+\rho E N E R_{\text {sel }}\right)$, and $\gamma E N E R E L_{\text {enel,sel }}$ and $\gamma E N E R N E_{\text {sel }}$ represent the distribution parameters corresponding to electricity and the non-electric energy bundle, respectively.

As already explained, at the forth nest the producers choose between the optimal consumption of natural gas ( $\left.E_{N I N P_{n g, s e l}}\right)$ and a coal-oil bundle $\left(E N E R C O_{\text {sel }}\right)$ according to another CES function:

$$
\begin{aligned}
& \text { ENERNE }_{\text {sel }}=a E N E R C O_{\text {sel }} \cdot\left(\gamma \text { ENINPG }_{n g, s e l} \cdot \text { ENINP }_{n g, s e l}^{-\rho E N E R C O}{ }_{s e l}+\gamma \text { ENERCO }_{\text {sel }} \cdot\right. \\
& \text { ENERCO } \left._{\text {sel }}^{-\rho E^{2} E R C O_{\text {sel }}}\right)^{-1 / \rho E N E R C O} \text { sel }
\end{aligned}
$$

Minimizing the costs function:

$\operatorname{Cost}_{\text {sel }}\left(\operatorname{ENINP}_{n g, s e l}\right.$, ENERCO $\left._{s e l}\right)=\sum_{n g}\left\{\left[P_{n g}+\sum_{c t m} t_{c i c t m}\right.\right.$ ctm,ng $\left.\left.\cdot P_{c t m}\right] \cdot\left(1+t_{i c_{n g}}\right) \cdot \operatorname{ENINP}_{n g, s e l}\right\}+$ PENERCO $_{\text {sel }} \cdot$ ENERCO $_{\text {sel }}$

subject to (19) yields the demand equations for natural gas and the coal-oil bundle:

$$
\begin{aligned}
& \text { ENINP }_{n g, s e l}=\operatorname{ENERNE}_{\text {sel }} \cdot\left\{\operatorname{PENERNE}_{\text {sel }} /\left\{\left[P_{n g}+\sum_{c t m} \operatorname{tcictm}_{c t m, n g} \cdot P_{c t m}\right] \cdot\right.\right. \\
& \left.\left.\left(1+t i c_{n g}\right)\right\}\right\}^{\sigma E N E R C O_{s e l}} \cdot \gamma E N I N P G_{n g, s e l}^{\sigma E N E R C O} O_{s e l} \cdot a E N E R C O_{s e l}^{\left(\sigma E N E R C O_{s e l}-1\right)}
\end{aligned}
$$

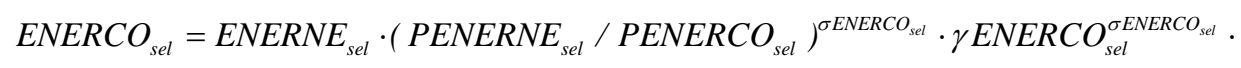

$$
\begin{aligned}
& \text { aENERCO } \mathrm{S}_{\text {sel }}^{\left(\sigma E N E R C \mathrm{O}_{\mathrm{sl}}-1\right)}
\end{aligned}
$$

and the associated zero profit condition: 
PENERNE $_{\text {sel }} \cdot$ ENERNE $_{\text {sel }}=\sum_{n g}\left\{\left[P_{n g}+\sum_{c t m}\right.\right.$ tcictm $\left._{c t m, n g} \cdot P_{c t m}\right] \cdot$

$\left(1+t i c_{n g}\right) \cdot$ ENINP $\left._{n g, s e l}\right\}+$ PENERCO $_{\text {sel }} \cdot$ ENERCO $_{\text {sel }}$

where $P E N E R C O_{\text {sel }}$ provides the price index corresponding to the coal-oil bundle, $\sigma E N E R C O_{\text {sel }}$ is the elasticity of substitution between natural gas and the coal-oil bundle, with $\sigma E N E R C O_{\text {sel }}=1 /\left(1+\rho E N E R C O_{\text {sel }}\right) \cdot \gamma E N I N P G_{n g, s e l}$ and $\gamma E N E R C O_{\text {sel }}$ represent the distribution parameters corresponding to natural gas and the coal-oil bundle, respectively.

At the fifth nest, the coal-oil bundle is given by another CES function of different energy inputs $\left(\right.$ ENINP $\left._{\text {enco,sel }}\right)$ :

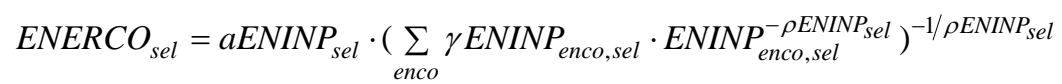

Minimizing the costs function:

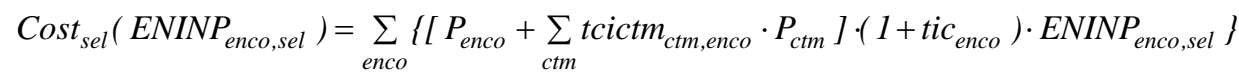

subject to (24) yields the demand equations for mining and quarrying of energy producing materials, products of coke and refined petroleum products:

ENINP $_{\text {enco }, \text { sel }}=\operatorname{ENERCO}_{\text {sel }} \cdot\left\{\text { PENERCO }_{\text {sel }} /\left\{\left[P_{\text {enco }}+\sum_{c t m} t c i c t m_{c t m, e n c o} \cdot P_{c t m}\right] \cdot\left(1+t i C_{\text {enco }}\right)\right\}\right\}^{\sigma E N I N P_{\text {sel }}} \cdot$

$\gamma \operatorname{ENINP}_{\text {enco,sel }}^{\sigma E N P_{\text {sel }}} \cdot a E N I N P_{\text {sel }}^{\left(\sigma E N I N P_{\text {sel }}-1\right)}$

and the associated zero profit condition:

PENERCO $_{\text {sel }} \cdot$ ENERCO $_{\text {sel }}=\sum_{\text {enco }}\left\{\left[P_{\text {enco }}+\sum_{c t m} t_{c i c t m}{ }_{c t m, \text { enco }} \cdot P_{c t m}\right] \cdot\left(1+\right.\right.$ tic $\left.\left._{\text {enco }}\right) \cdot E^{2} I N P_{\text {enco }, \text { sel }}\right\}$

where $\sigma E N I N P_{\text {sel }}$ is the elasticity of substitution between mining and quarrying of energy producing materials, products of coke and refined petroleum products, with $\sigma E N I N P_{\text {sel }}=1 /\left(1+\rho E N I N P_{\text {sel }}\right)$. Following the same notational rules, $\gamma E N I N P_{\text {enco,sel }}$ represents the distribution parameters corresponding to mining and quarrying of energy producing materials, products of coke and refined petroleum products, respectively.

The nested production structure of all other branches of activity is similar to the one for electricity, gas and steam sector, except for the primary energy sectors, whose particular structure will be discussed in detail below. For the other sectors, the only difference with the sel sector stands at the fourth nest where the non-electric energy bundle is not split into a Coal-Oil composite on the one hand and other energy inputs on the other, but rather defined by a CES function of all non-electric energy products: mining and quarrying of energy producing materials, products of coke, refined petroleum products and natural gas (see Figure 2). The demand equations for these energy inputs are discussed below, whereas all other demand and zero-profit equation are identical to the one described above. The particular structure that is assumed for the electricity, gas and steam sector reflects the relative importance that Coal and Oil play in the production of this sector. 


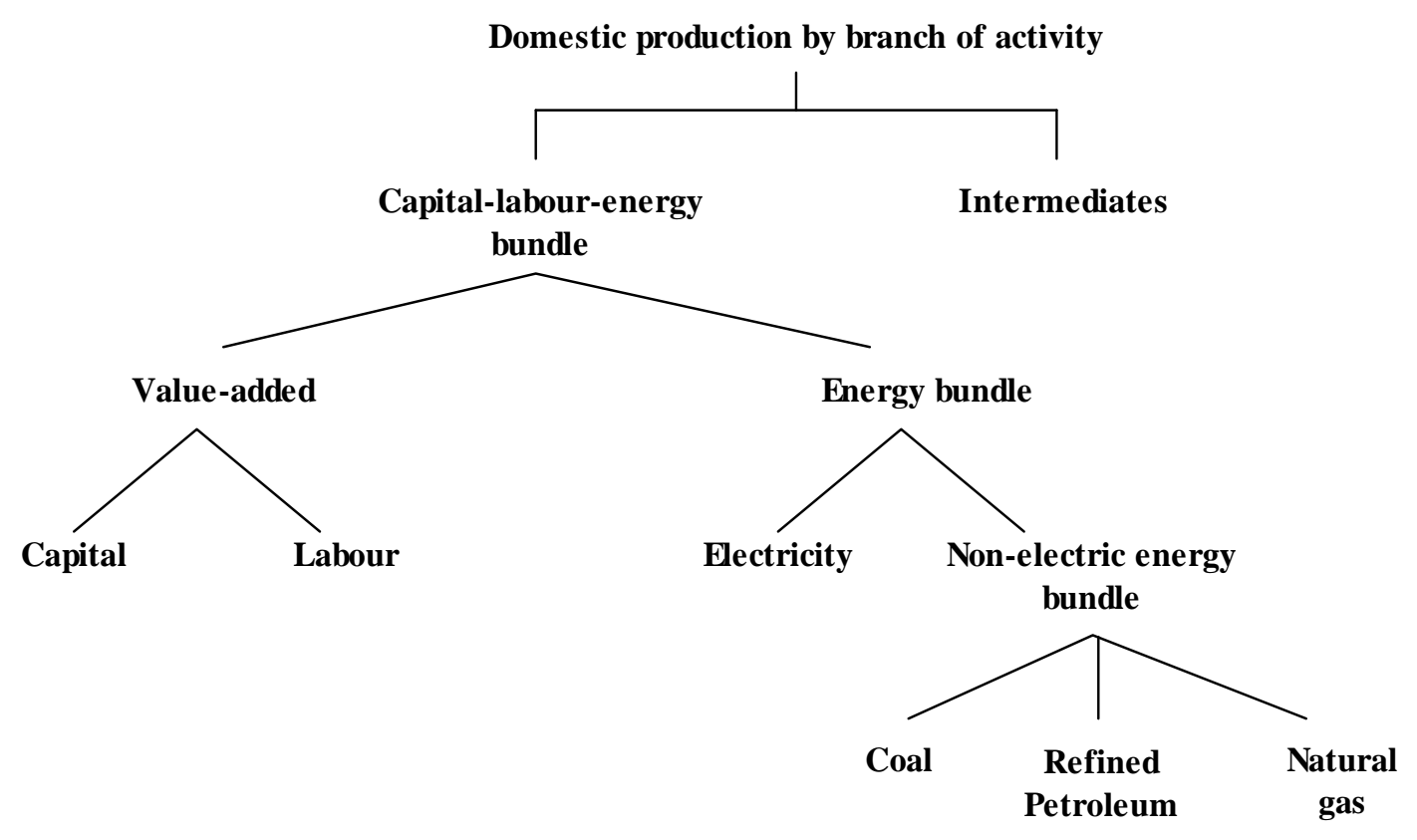

Figure 2. The nested Leontief and CES production technology for the domestic production of all branches of activity except the electricity sector and primary energy sectors.

As explained, at the fourth nest, the non-electric energy bundle ( $E N E R N E_{\text {nsel }}$ ) in branch nsel is given by another CES function of various non-electric energy inputs $\left(E_{\text {NINP }}\right.$ ennel,nsel $)$ :

ENERNE $_{\text {nsel }}=a E N I N P_{n s e l} \cdot\left(\sum_{\text {ennel }} \gamma \operatorname{ENINP}_{\text {ennel, nsel }} \cdot E N I N P_{\text {ennel, }, n s e l}^{-\rho E N P_{n s e l}}\right)^{-1 / \rho E N I N P_{n s e l}}$

Minimizing the costs function:

$\operatorname{Cost}_{\text {nsel }}\left(\right.$ ENINP $\left._{\text {ennel, nsel }}\right)=\sum_{\text {ennel }}\left\{\left[P_{\text {ennel }}+\sum_{c t m} t c i c t m_{c t m, \text { ennel }} \cdot P_{c t m}\right] \cdot\left(1+\right.\right.$ tic $\left._{\text {ennel }}\right) \cdot$ ENINP $\left._{\text {ennel, nsel }}\right\}$

subject to (28) yields the demand equations for mining and quarrying of energy producing materials, products of coke, refined petroleum products and natural gas:

ENINP $_{\text {ennel, nsel }}=\operatorname{ENERNE}_{\text {nsel }} \cdot\left\{\operatorname{PENERNE}_{\text {nsel }} /\left\{\left[P_{\text {ennel }}+\sum_{c t m} t_{c i c t m_{c t m, e n n e l}} \cdot P_{c t m}\right] \cdot\left(1+t_{i C_{\text {ennel }}}\right)\right\}\right\}^{\sigma E N I N P_{\text {nsel }}} \cdot$

$\gamma \operatorname{ENINP}_{\text {ennel, }, \text { ssel }}^{\sigma \text { sel }} \cdot \operatorname{aENINP_{\text {sel}}^{(\sigma ENINP_{\text {sel}}-1)}}$

and the associated zero profit condition:

$\operatorname{PENERNE}_{\text {nsel }} \cdot$ ENERNE $_{\text {nsel }}=\sum_{\text {ennel }}\left\{\left[P_{\text {ennel }}+\sum_{c t m}\right.\right.$ tcictm $\left._{c t m, \text { ennel }} \cdot P_{c t m}\right] \cdot\left(1+\right.$ tic $\left._{\text {ennel }}\right) \cdot$ ENINP $\left._{\text {ennel, nsel }}\right\}$

where $\sigma E N I N P_{n s e l}$ represent the elasticities of substitution between mining and quarrying of energy producing materials, products of coke, refined petroleum products and natural 
gas in branch $n$ sel, with $\sigma E N I N P_{\text {nsel }}=1 /\left(1+\rho E N I N P_{\text {nsel }}\right)$. Besides, $\gamma E N I N P_{\text {ennel,nsel }}$ represent the distribution parameters corresponding to these non-electric energy products.

Capital is industry specific, introducing rigidities in the capital market. The inter-sectoral wage differential is a parameter derived as the ratio between the wage by branch and the average wage in the domestic employment (Dervis, De Melo and Robinson, 1982). By holding the inter-sectoral wage differentials constant in counterfactual policy simulations, rigidities in the labour market can be introduced.

Each branch of activity in RusMod produces several types of goods and services. The optimal allocation of domestic production per sector over the different types of commodities is given by a Leontief function:

$X D D E_{c}=\sum_{s} i o C_{s, c} \cdot X D_{s}$

where $X D D E_{c}$ represents the domestic production of commodity $c$ by different branches, supplied on the home and foreign markets, $X D_{s}$ is the domestic production of branch $s$, and $i o C_{s, c}$ is a fixed coefficient expressing the share of production of commodity $c$ by the industry $s$ per unit of production of industry $s$.

The corresponding zero profit condition is given by:

$P D_{s}=\sum_{c} i o C_{s, c} \cdot P D D E_{c}$

where $P D D E_{c}$ is the domestic price of commodity $c$ supplied on the home and foreign markets and $P D_{s}$ is the price index corresponding to domestic production by branch $s$.

For the primary energy sectors (producing oil and natural gas), a specific production structure is assumed, that emphasizes the dependency of both sectors on the availability of the particular natural resources that represent the lion's share of their production. The prominence of these resources is reflected by their inclusion in the first nest, defining how a fixed factor (the natural resource) and a non-resource bundle (NRES) including all other commodities and production factors are combined in a CES function to reach total production:

$X D_{\text {oils }}=a F R E S_{\text {oils }} \cdot\left[\gamma F R E S_{\text {oils }} \cdot F F_{\text {oils }}^{-\rho F R E S_{\text {oils }}}+\gamma F N R E S_{\text {oils }} \cdot N R E S_{\text {oils }}^{-\rho F R E S_{\text {oils }}}\right]^{-1 / \rho F R E S_{\text {oils }}}$

Minimization of the associated cost function:

$\operatorname{Cost}_{\text {oils }}\left(F F_{\text {oils }}, N R E S_{\text {oils }}\right)=P F F_{\text {oils }} \cdot F F_{\text {oils }}+P N R E S_{\text {oils }} \cdot N R E S_{\text {oils }}$,

subject to (34) yields the familiar factor demand equations:

$$
\begin{aligned}
& F F_{\text {oils }}=X D_{\text {oils }} \cdot\left(P D_{\text {oils }} / P F F_{\text {oils }}\right)^{\sigma F R E S_{\text {oils }}} \cdot \gamma F R E S_{\text {oils }}^{\sigma F R E S_{\text {oils }}} \cdot a F R E S_{\text {oils }}^{\left(\sigma F E S_{\text {oils }}-1\right)} \\
& N R E S_{\text {oils }}=X D_{\text {oils }} \cdot\left(P D_{\text {oils }} / P N R E S_{\text {oils }}\right)^{\sigma F R E S_{\text {oils }}} \cdot \gamma F N R E S_{\text {oils }}^{\sigma F R E S_{\text {olls }}} \cdot a F R E S_{\text {oils }}^{\left(\sigma F R E S_{\text {oils }}-1\right)}
\end{aligned}
$$

and the associated zero profit condition:

$P D_{\text {oils }} \cdot\left(1-t p_{\text {oils }}\right) \cdot X D_{\text {oils }}=P F F_{\text {oils }} \cdot F F_{\text {oils }}+P N R E S_{\text {oils }} \cdot N R E S_{\text {oils }}$ 
where $P D_{\text {oils }}$ is the price index of domestic production of crude oil and natural gas, $P F F_{\text {oils }}$ gives the return to natural resources and $P N R E S_{\text {oils }}$ provides the price index corresponding to the non-resource input bundle. The tax rate on production of crude oil and natural gas is given by $t p_{\text {oils }}$. The elasticity of substitution between natural resources and the nonresource input bundle is provided by $\sigma F R E S_{\text {oils }}$, where $\sigma F R E S_{\text {oils }}=1 /\left(1+\rho F R E S_{\text {oils }}\right)$, and $\gamma F R E S_{\text {oils }}$ and $\gamma F N R E S_{\text {oils }}$ represent the distribution parameters corresponding to natural resources and non-resource input bundle, respectively.

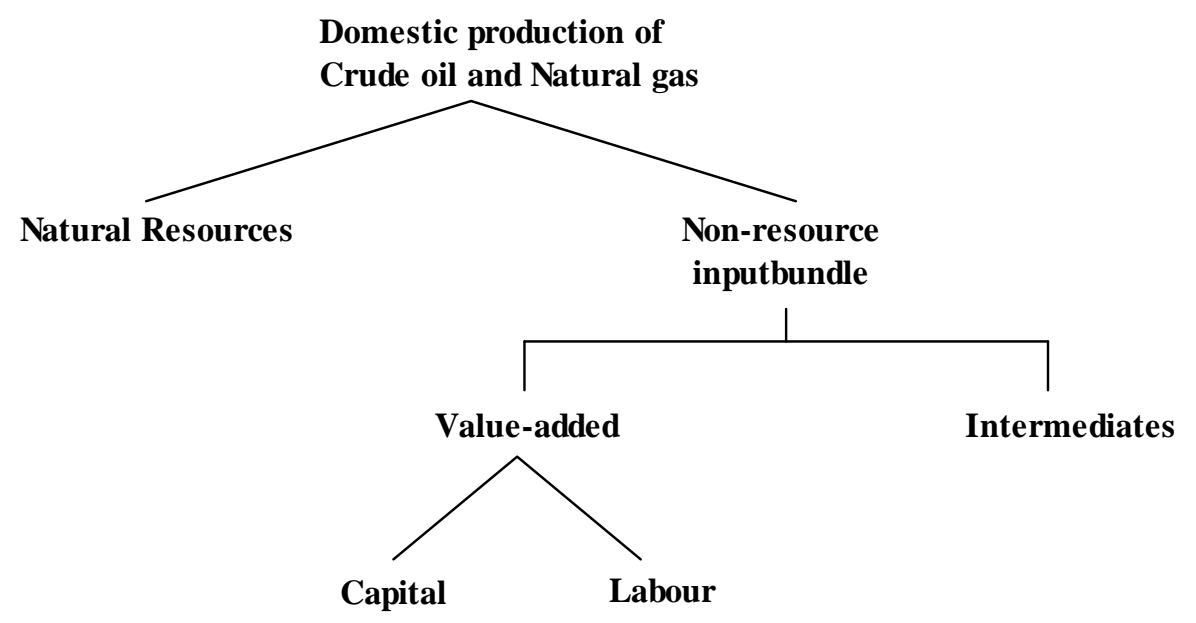

Figure 3: Production structure in the oil and natural gas sectors

At the second nest, the non-resource bundle is defined by a Leontief function of Valueadded and all intermediates. As a consequence, minimization of the cost function subject to this Leontief function yields an optimal allocation of inputs that is a fixed fraction of the total non-resource bundle:

$K L_{\text {oils }}=a K L_{\text {oils }} \cdot N R E S_{\text {oils }}$.

where $a K L_{\text {oils }}$ is the fixed coefficient relating value-added to the non-resource input bundle. Similarly, total intermediate inputs used by industry oils $\left(I_{\text {oils }}\right)$ are derived as:

$I O_{\text {oils }}=\sum_{c} i o_{c, \text { oils }} \cdot N R E S_{\text {oils }}$

where $i i_{c, \text { oils }}$ are the technical coefficients. Thus, the non-resource input bundle at basic prices is given by the sum of value added ( $K L_{\text {oils }}$ ) for branch oils valued at basic prices $\left(P K L_{\text {ois }}\right)$ and intermediate commodities used by sector oils valued at the price of the commodity $c\left(P_{c}\right)$.

$\mathrm{PNRES}_{\text {oils }} \cdot N R E S_{\text {oils }}=P K L_{\text {oils }} \cdot K L_{\text {oils }}+\sum_{c}\left(i o_{c, \text { oils }} \cdot N R E S_{\text {oils }} \cdot P_{c}\right)$ 
Similar to the structure assumed in all other sectors, value-added in the crude oil and natural gas sectors is given at the third nest as a CES aggregation of capital $\left(K S K_{\text {oils }}\right)$ and labour $\left(L S K_{\text {oils }}\right)$ :

$$
K L_{\text {oils }}=a F_{\text {oils }} \cdot\left[\gamma F K_{\text {oils }} \cdot K S K_{\text {oils }}^{-\rho F_{\text {oils }}}+\gamma F L_{\text {oils }} \cdot L S K_{\text {oils }}^{-\rho F_{\text {oils }}}\right]^{-1 / \rho F_{\text {oils }}}
$$

Minimizing the associated cost function:

$$
\begin{aligned}
\operatorname{Cost}_{\text {sel }}\left(K S K_{\text {sel }}, L S K_{\text {sel }}\right)= & {\left[P K_{\text {sel }} \cdot\left(1+t k_{\text {sel }}\right)+d_{\text {sel }} \cdot P I_{\text {sel }}\right] \cdot K S K_{\text {sel }}+} \\
& {\left[P L \cdot\left(1+\text { premLSK }_{\text {sel }}\right) \cdot\left(1+t l_{\text {sel }}\right)\right] \cdot L S K_{\text {sel }} }
\end{aligned}
$$

subject to (9) yields the factor demand equations for capital and labour:

$$
\begin{aligned}
& K S K_{\text {sel }}=K L_{\text {sel }} \cdot\left\{P K L_{\text {sel }} /\left[P K_{\text {sel }} \cdot\left(1+t k_{\text {sel }}\right)+d_{\text {sel }} \cdot P I_{\text {sel }}\right]\right\}^{\sigma F_{s e l}} \cdot \gamma F K_{\text {sel }}^{\sigma F_{\text {sel }}} \cdot a F_{\text {sel }}^{\left(\sigma F_{s e l}-1\right)} \\
& L S K_{\text {sel }}=K L_{\text {sel }} \cdot\left\{P K L_{\text {sel }} /\left[P L \cdot\left(1+\operatorname{premLSK}_{\text {sel }}\right) \cdot\left(1+t l_{\text {sel }}\right)\right]\right\}^{\sigma F_{\text {sel }}} \cdot \gamma F L_{\text {sel }}^{\sigma F_{\text {sel }}} \cdot a F_{\text {sel }}^{\left(\sigma F_{s e l}-1\right)}
\end{aligned}
$$

and the corresponding zero profit condition:

$$
\begin{aligned}
& P K L_{\text {sel }} \cdot K L_{\text {sel }}=\left[P K_{\text {sel }} \cdot\left(1+t k_{\text {sel }}\right)+d_{\text {sel }} \cdot P I_{\text {sel }}\right] \cdot K S K_{\text {sel }}+P L \cdot\left(1+\operatorname{premLSK}_{\text {sel }}\right) . \\
& {\left[1+t l_{\text {sel }}\right] \cdot L S K_{\text {sel }}}
\end{aligned}
$$

where the symbols used are identical to the equations (10) - (13).

\subsection{Households, Government, and the Rest of the World}

In addition to the firms, two other institutional units are distinguished in the model: households and the government. Russia's trade and capital flows with the Rest of the World (ROW) are modelled as well.

The households provide production factors that are used by the firms in their production process. They are nearly completely responsible for the labour supply (the remainder being provided by ROW) and besides provide a share of capital. In turn for this, the households receive factor incomes, that are supplemented by unemployment benefits and net government transfers to yield total income. The absolute and relative sizes of the different components of total household's income can be derived from the SAM that was used as basis for the CGE model.

The households' expenditures can be categorized into three categories: taxes, savings and private consumption. Although the initial choices made can be easily found in the SAM, in order to run simulations or produce projections, behavioral assumptions need to be made describing the choices that the households face and make. In order to do this, it is assumed that there is only one representative household in the economy, that receives all income going to the households, and whose expenditures amount the aggregation of expenditures by individual households in the economy. This household is assumed to face an income tax rate, that determines the share of its total income that it will have at its disposal. Of this disposable income, it saves a proportion according to its propensity to save. The remainder, its consumption budget, is spent on the 20 commodities in the 
economy. When allocating the consumption budget to each of the commodities, the household is assumed to maximize a Stone-Geary (Linear Expenditure System) utility function. In this function, the household has subsistence levels that determine the minimum quantity of each commodity that it should consume. Any budget that is left after purchasing these quantities will be spent according marginal budget shares.

The resulting private demand for commodities is only one of the demand categories over which total supply (consisting of domestic supply and imports) is divided. The other categories are: intermediate consumption, public demand, investment demand, change in inventories and exports. Public consumption is the consumption by the government, that divides it budget according to a Leontief function over the particular selection of commodities that it demands. Besides, the government saves a proportion of its revenues (or lends it, according to whether there is a budget surplus or deficit, respectively), that is constructed as the difference between total governmental revenues (i.e. net tax revenues, property income (including royalties on natural resources), operating surplus, received current transfers and social contributions) and total governmental expenditures, including social benefits, property income, other transfers paid and expenditures for public consumption.

The demand for investment goods is determined by an investment bank, that allocates total savings minus depreciation over the different commodities according to a Leontief function.

The incorporation of dynamics in the model is reached by creating a sequence of yearly temporal equilibria, that are linked to each other through the evolution of the capital stock in the economy, facing capital accumulation through investment and depreciation. Thus, this endogenous determination of investment behaviour is essential for the dynamic characteristics of the model. Investment and capital accumulation in year $t$ depend on expected rates of return for year $t+1$, which are determined by actual returns on capital in year $t$.

Next to the investment stock, the availability of natural resources over time is modeled endogenously as well, by taking into account the crude oil and natural gas reserves and their depletion profile. Whereas the extraction of natural resources depletes the reserves, they are on the other hand supplemented by the discovery of new reserves. In the model, both the extraction rate, which is the speed at which the existing proven reserves are depleted, and the discovery rate, which is the rate at which new reserves are discovered (as a proportion of the total estimated availability of unproven natural resource reserves) are determined endogenously.

\subsection{Green House Gas Emissions}

RusMod models GHG emissions explicitly by linking them directly to the consumption of energy. By specifying the energy consumption by the different agents and branches of 
activity in the model in detail, this link provides an equally detailed insight in the contribution that each agent makes to total GHG emissions. Since the CGE model provides this detailed disaggregation into different agents and multiple sectors, and particularly takes into account how the various agents depend on each other, it facilitates a thorough study on the various contributors to GHG emissions. Especially when incorporating dynamics in the analysis and running models over time, this methodology provides a very useful set of tools to acquire insights in the evolution of GHG emissions in general, and more particularly into the relative share of the contribution that every type of energy, all branches of activity, or the households make to total emissions.

In the model, two types of emitters are distinguished. The biggest contributors to total emissions are the different branches of activity. Their emissions stem from the intermediate consumption of energy commodities as part of their production process, as was described in the section on the sectoral production structure. Besides, the residential sector contributes by consuming energy commodities, mainly for heating purposes.

In order to link the economic data on consumption and the more physically oriented data on emissions, the consumption of energy commodities needs to be expressed in units of energy, rather than in Rubles. In line with the data on energy consumption and green house gas emissions that served as the source for this study, in the model the energy consumption is expressed in kilo tones of oil equivalents. The ratio between energy consumption in Rubles and energy consumption in ktoe expresses the implicit price related to the energy vector. Subsequently, the ktoe-consumption of each type of energy commodity by each type of emitter is linked to actual GHG emissions through emission factors. These are typically expressed in kt or Mt per ktoe, depending on the type of GHG, and describe the amount of emissions of every type of GHG that is caused by combustion of each of the particular energy commodities. They typically vary over the sectors, due to differences in the amount of pollution caused by employment of dirty or cleaner technologies in different sectors.

When modeling the evolution of GHG emissions over time, there are various parameters to take into account. One of them is the amount of emissions associated with the combustion of a particular fuel in a particular sector, like described above. Another important factor is the energy intensity, that determines how much of every energy commodity is required for production by a particular branch of activity. This efficiency typically improves over time, which implies that the amount of energy required per unit of production decreases. As a result, the emissions per unit of production will decrease accordingly, provided that no changes occur to the emission factors. 


\section{ASSUMPTIONS}

The full time period under consideration in RusMod, 2003-2020, needs to be split in two parts, according to the availability of actual historical data until 2007, and the necessity to include projections starting from 2008. For the first part of the sample, the model solves dynamically according to a path of variables like GDP growth, population growth and energy efficiency that are imposed to be reached exogenously based on observations of these variables since 2003, the base year of the study. Next, in the second part of the sample, projections are used, that allow for the formulation of various scenarios.

Tables 3 and 4 report the macroeconomic series that are underlying the forecasts that will be reported in the next section. In order to interpret these assumptions and results properly, it is important to elicit one methodological choice. As highlighted above, in the first period of the subsample, 2003-2007, the model is reproducing historical figures on GDP growth. As a consequence, factor productivity is left free and adapts according to the evolution of GDP. However, in the remainder of the sample, 2008-2020, it is labour productivity that will be assumed to be determined exogenously, and real GDP will adapt. This is particularly sensible in the light of the evolution of energy efficiency, which will play an important role in the empirical analyses that will follow; the impact of different efficiency scenarios on real GDP growth will be a major concern. In order to enable this variable to be endogenously determined and still be able to identify different scenarios of economic growth, labour productivity will capture the degree of acceleration starting from 2008. In line with official Long Run scenarios provided by the Russian government, table 3 reports three series, yielding 260, 240 and 200 percent improvements of labour productivity respectively, between 2006 and 2020. The first scenario of these three is the innovative scenario that is chosen as baseline by the European Commission in its long run projections for Russia.

Table 3: GDP deflator and labour productivity annual growth rates (in percent)

\begin{tabular}{lrrrrrrrrr}
\hline & $\mathbf{2 0 0 4}$ & $\mathbf{2 0 0 5}$ & $\mathbf{2 0 0 6}$ & $\mathbf{2 0 0 7}$ & $\mathbf{2 0 0 8}$ & $\mathbf{2 0 0 9}$ & $\mathbf{2 0 1 0}$ & $\mathbf{2 0 1 1}$ & $\mathbf{2 0 1 2}$ \\
\hline GDP deflator & 20.1 & 19.2 & 15.8 & 13.5 & 23.9 & 9.5 & 7.8 & 7.7 & 7.7 \\
Labour Productivity & & & & & & & & & \\
- Innovative & - & - & 6.00 & 5.59 & 7.92 & 6.83 & 7.07 & 6.95 & 6.46 \\
- Energy and Raw Materials & - & - & 6.00 & 5.12 & 7.26 & 6.26 & 6.49 & 6.37 & 5.93 \\
- Inertial & - & - & 6.00 & 4.03 & 5.71 & 4.93 & 5.10 & 5.01 & 4.66 \\
\hline
\end{tabular}

Source: Commission Services

Table 3: GDP deflator and labour productivity annual growth rates (in percent)

\begin{tabular}{lrrrrrrrr}
\hline & $\mathbf{2 0 1 3}$ & $\mathbf{2 0 1 4}$ & $\mathbf{2 0 1 5}$ & $\mathbf{2 0 1 6}$ & $\mathbf{2 0 1 7}$ & $\mathbf{2 0 1 8}$ & $\mathbf{2 0 1 9}$ & $\mathbf{2 0 2 0}$ \\
\hline GDP deflator & 7.3 & 7.2 & 6.2 & 4.8 & 4.5 & 3.9 & 3.9 & 3.7 \\
Labour Productivity & & & & & & & & \\
- Innovative & 6.76 & 7.06 & 7.66 & 7.98 & 7.72 & 7.06 & 6.93 & 6.53 \\
- Energy and Raw Materials & 6.20 & 6.48 & 7.03 & 7.32 & 7.08 & 6.48 & 6.35 & 5.99 \\
- Inertial & 4.88 & 5.09 & 5.53 & 5.76 & 5.57 & 5.10 & 5.00 & 4.71 \\
\hline
\end{tabular}

Source: Commission Services 
Table 3 reports the macro economic variables at the most aggregated level. The GDP deflator and the evolution of labour productivity under the first, innovative, scenario are obtained from a document called 'Long-run Macro Projections for Russia', provided by the European Commission. The other two scenarios are based on the first one, but scaled down in order to be in line with the Russian governmental projections.

Table 4: Labour force assumptions

\begin{tabular}{lrrrrrrrrr}
\hline & 2003 & $\mathbf{2 0 0 4}$ & $\mathbf{2 0 0 5}$ & $\mathbf{2 0 0 6}$ & $\mathbf{2 0 0 7}$ & $\mathbf{2 0 0 8}$ & $\mathbf{2 0 0 9}$ & $\mathbf{2 0 1 0}$ & $\mathbf{2 0 1 1}$ \\
\hline Active population (in millions) & 72.7 & 73.1 & 73.1 & 73.2 & 74.9 & 74.8 & 74.6 & 74.2 & 73.7 \\
Active population Growth rate & - & 0.53 & 0.07 & 0.09 & 2.38 & -0.15 & -0.29 & -0.58 & -0.59 \\
Unemployment rate & 8.6 & 8.2 & 8.2 & 8.2 & 8.2 & 8.2 & 8.2 & 8.2 & 8.2 \\
\hline
\end{tabular}

Source: Commission Services

Table 4: Labour force assumptions

\begin{tabular}{lrrrrrrrrr}
\hline & $\mathbf{2 0 1 2}$ & $\mathbf{2 0 1 3}$ & $\mathbf{2 0 1 4}$ & $\mathbf{2 0 1 5}$ & $\mathbf{2 0 1 6}$ & $\mathbf{2 0 1 7}$ & $\mathbf{2 0 1 8}$ & $\mathbf{2 0 1 9}$ & $\mathbf{2 0 2 0}$ \\
\hline Active population (in millions) & 73.5 & 73.0 & 72.5 & 72.0 & 71.2 & 70.6 & 70.2 & 69.7 & 69.4 \\
Active population Growth rate & -0.30 & -0.74 & -0.60 & -0.75 & -1.06 & -0.92 & -0.62 & -0.62 & -0.47 \\
Unemployment rate & 8.2 & 8.2 & 8.2 & 8.2 & 8.2 & 8.2 & 8.2 & 8.2 & 8.2 \\
\hline
\end{tabular}

Source: Commission Services

Table 5: Emission Factors

\begin{tabular}{|c|c|c|c|}
\hline Emission factors ( $k t / k t o e)$ & Refined petroleum and other fuels & Natural gas & Coal \\
\hline Electricity & 3.00 & 2.34 & 4.27 \\
\hline Crude oil & 3.50 & 2.34 & \\
\hline Refined petroleum and other fuels & 7.17 & & 4.01 \\
\hline Natural gas & 6.12 & 2.34 & \\
\hline Coal & 2.36 & & 4.01 \\
\hline Ferrous metallurgy & 2.69 & 2.34 & 7.31 \\
\hline Nonferrous metallurgy & 2.84 & 2.34 & 4.06 \\
\hline Chemical and petrochemical industry & 2.71 & 2.34 & 4.52 \\
\hline Machinery & 2.42 & 2.34 & 4.29 \\
\hline Lumber, pulp and paper industry & 2.57 & 2.33 & 4.55 \\
\hline Construction materials & 2.53 & 2.32 & 4.07 \\
\hline Light industry & 2.42 & 2.35 & 3.74 \\
\hline Food processing industry & 2.60 & 2.34 & 3.97 \\
\hline Other industries & 3.80 & 2.34 & 3.68 \\
\hline Construction & 2.41 & 2.32 & 4.07 \\
\hline Agriculture and forestry & 2.83 & 2.34 & 3.96 \\
\hline Transport and communication & 2.36 & 2.34 & \\
\hline Trade, brokerage and catering & 2.38 & 2.34 & 3.88 \\
\hline Housing, R\&D and other services & 2.90 & 2.33 & 3.91 \\
\hline Government and financial services & 2.39 & 2.34 & 3.88 \\
\hline
\end{tabular}

Source: Commission Services and own calculation 
Next to the GDP growth, projections on the size of the active population and the level of unemployment are used, that were obtained from the same source provided by European Commission services and the IMF country report for Russia from 2005, respectively. The numbers in table 4 show that the active population is expected to have reached its peak in 2007. In the following years, it will start to decrease at a ratio that grows from 0.15 to over one percent in 2016. The unemployment rate is assumed to be constant over the period at its level in 2004 of 8.2 percent.

Table 6: Energy intensity assumptions (annual growth rates)

$\begin{array}{lllllllll}2004 & 2005 & 2006 & 2007 & 2008 & 2009 & 2010 & 2011 & 2012\end{array}$

Energy intensity

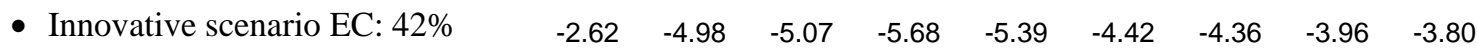

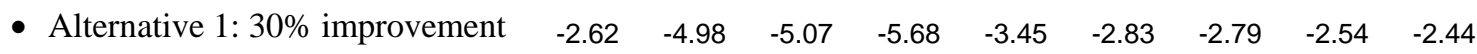

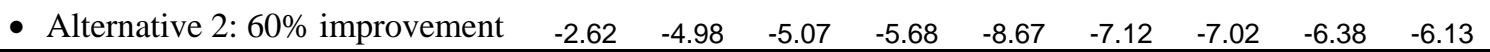

Source: Commission Services and own calculation

Table 6: Energy intensity assumptions (annual growth rates)

\begin{tabular}{lllllllll}
\hline & $\mathbf{2 0 1 3}$ & $\mathbf{2 0 1 4}$ & $\mathbf{2 0 1 5}$ & $\mathbf{2 0 1 6}$ & $\mathbf{2 0 1 7}$ & $\mathbf{2 0 1 8}$ & $\mathbf{2 0 1 9}$ & $\mathbf{2 0 2 0}$ \\
\hline Energy intensity & & & & & & & & \\
- Innovative scenario EC: 42\% & -3.75 & -4.25 & -4.62 & -4.41 & -4.35 & -3.99 & -3.92 & -3.70 \\
- Alternative 1: 30\% improvement & -2.40 & -2.72 & -2.96 & -2.82 & -2.79 & -2.56 & -2.51 & -2.37 \\
- Alternative 2: 60\% improvement & -6.04 & -6.85 & -7.43 & -7.10 & -7.00 & -6.43 & -6.31 & -5.96 \\
\hline
\end{tabular}

Source: Commission Services and own calculation

Table 5 reports the emission factors used in the current version of the model, for CO2 emissions by each of the three energy categories (refined oil, coal and natural gas) over the 20 sectors. In this table, no emission factor is assigned to branches of activity that do not consume a particular energy commodity in their production process, e.g. the coal sector does not consume refined petroleum and natural gas, and the transport sector does not consume coal.

Table 6 reports the assumptions that were made regarding energy intensity, on the aggregate level. Main source for these projections is the document 'Long-run Macro Projections for Russia', provided by the European Commission. The first, innovative scenario is constructed by figures from this file. Under this scenario, overall energy intensity will improve by 43 percent, which is slightly more than a 40 percent improvement that was demanded by president Medvedev in a recent decree. The other two scenarios are obtained by scaling the annual growth rates of the innovative scenario down and up, respectively. For the disaggregation of the overall efficiency gains over the branches of activity, data on Romania were used, combined with a World Bank report on the efficiency growth potentials for Russia. Hence, the overall efficiency gains vary over the different scenarios, whereas the relative contribution of each of the twenty sectors in the model is fixed. 
The specification of the model is based on the assumption of exogenously fixed world prices of commodities; both the prices of exports and imports remain constant over time for all goods except energy commodities. Projections on the yearly development of energy prices, as reported in table 7 , are derived from a POLES report on post-Kyoto scenarios obtained from the EC. Finally, the exchange rate is set to grow at a rate equal to the growth rate of the GDP deflator.

\section{Table 7: Development of World prices of energy commodities}

\begin{tabular}{lrrrrrrrrr}
\hline & $\mathbf{2 0 0 4}$ & $\mathbf{2 0 0 5}$ & $\mathbf{2 0 0 6}$ & $\mathbf{2 0 0 7}$ & $\mathbf{2 0 0 8}$ & $\mathbf{2 0 0 9}$ & $\mathbf{2 0 1 0}$ & $\mathbf{2 0 1 1}$ & $\mathbf{2 0 1 2}$ \\
\hline Electricity & 8.68 & 8.68 & 7.05 & 7.05 & 7.05 & 7.05 & 7.05 & -1.99 & -1.99 \\
Crude oil & 6.46 & 6.46 & 7.27 & 7.27 & 7.27 & 7.27 & 7.27 & -1.03 & -1.03 \\
Refined petroleum and other fuels & 9.79 & 9.79 & 11.02 & 11.02 & 11.02 & 11.02 & 11.02 & -1.56 & -1.56 \\
Natural gas & 10.01 & 10.01 & 8.13 & 8.13 & 8.13 & 8.13 & 8.13 & -2.29 & -2.29 \\
Coal & 13.73 & 13.73 & 2.13 & 2.13 & 2.13 & 2.13 & 2.13 & 2.30 & 2.30 \\
\hline
\end{tabular}

Source: Commission Services and own calculation

Table 7: Development of World prices of energy commodities

\begin{tabular}{lrrrrrrrr}
\hline & $\mathbf{2 0 1 3}$ & $\mathbf{2 0 1 4}$ & $\mathbf{2 0 1 5}$ & $\mathbf{2 0 1 6}$ & $\mathbf{2 0 1 7}$ & $\mathbf{2 0 1 8}$ & $\mathbf{2 0 1 9}$ & $\mathbf{2 0 2 0}$ \\
\hline Electricity & -1.99 & -1.99 & -1.99 & -1.99 & -1.99 & -1.99 & -1.99 & -1.99 \\
Crude oil & -1.03 & -1.03 & -1.03 & -1.03 & -1.03 & -1.03 & -1.03 & -1.03 \\
Refined petroleum and other fuels & -1.56 & -1.56 & -1.56 & -1.56 & -1.56 & -1.56 & -1.56 & -1.56 \\
Natural gas & -2.29 & -2.29 & -2.29 & -2.29 & -2.29 & -2.29 & -2.29 & -2.29 \\
Coal & 2.30 & 2.30 & 2.30 & 2.30 & 2.30 & 2.30 & 2.30 & 2.30 \\
\hline
\end{tabular}

Source: Commission Services and own calculation

\section{Projections}

Based on the assumptions that were elicited in the previous section, projections are obtained for all endogenous variables in the model between 2008 and 2020. Various scenarios are analysed, regarding the evolution of energy intensity, economic growth and the application of a policy instrument: the introduction of a CO2-price. As a starting point, a baseline scenario will be defined and analysed that will act as reference for the other scenarios under consideration in this section. This baseline scenario can be seen as a formulation of the most likely path of evolution for the Russian economy, based primarily on sources provided by the European Commission and the Russian government.

\subsection{The baseline scenario}

Most of the assumptions underlying the baseline scenario have been exposed in the previous section. However, two of them require particular attention, since they will define the differences between the several scenarios under consideration in the following 
sections. Labour productivity is used as driver of economic growth, and is assumed to grow by 260\% between 2006 and 2020. This is in line with an evolution marked as innovative scenario by the European Commission, and besides corresponds to an official scenario with the same name provided by the Russian government. Energy efficiency, defined as the total consumption of energy resources in physical terms per unit of GDP, is assumed to grow according to the same innovative scenario by $42.95 \%$ between 2007 and 2020. This is in line with a recent decree by president Medvedev in which he calls for an improvement in energy intensity of $40 \%$ in the same period.

Tables $8 \mathrm{a}$ and $8 \mathrm{~b}$ present in detail the evolution of the GDP and its various components under the baseline scenario. Whereas table 8a provides this evolution in levels, table 8b presents annual growth rates. The results exhibit an overall GDP growth in the time period 2007-2020 by a factor 2.33, with annual growth rates starting at $7.8 \%$ in 2008 and fluctuating between 6 and $7 \%$ over the rest of the sample. The share of private consumption in GDP grows over the sample period, from 50.7\% in 2003 to $54.4 \%$ in 2020. While the role of governmental consumptive spending in the domestic product declines slightly, the increase in private consumption and particularly gross fixed investment comes at the expense of the foreign balance, showing only a minor increase in real terms over the entire time span, driven by growth rates of imports that are consistently higher than export growth.

In table 11, the projected CO2 emission are reported, split up in a contribution made by the production sectors in the economy (including the local and federal governments) and a share of the residential households. The latter diminished over the years, from a share of more than $9 \%$ in 2008 to just $7.4 \%$ in 2020. Tables 14 and 15 in the appendix provide a further disaggregation into the twenty branches of activity of the $\mathrm{CO} 2$ emissions.

Table 8a: Macroeconomic projections (bln roubles)

\begin{tabular}{lrrrrrrrr}
\hline & $\mathbf{2 0 0 3}$ & $\begin{array}{c}\text { Share in } \\
\text { GDP (\%) }\end{array}$ & $\mathbf{2 0 0 7}$ & $\mathbf{2 0 0 8}$ & $\mathbf{2 0 0 9}$ & $\mathbf{2 0 1 0}$ & $\mathbf{2 0 1 1}$ & $\mathbf{2 0 1 2}$ \\
\hline GDP & $13,201.1$ & 100.0 & $17,481.4$ & $18,857.9$ & $20,146.5$ & $21,512.0$ & $22,992.5$ & $24,478.3$ \\
Private consumption & $6,694.5$ & 50.7 & $9,392.6$ & $10,030.2$ & $10,678.0$ & $11,375.1$ & $12,152.6$ & $12,949.1$ \\
Government consumption & $2,332.3$ & 17.7 & $2,910.9$ & $3,155.6$ & $3,370.8$ & $3,595.7$ & $3,831.8$ & $4,068.1$ \\
Gross fixed investment & $2,669.9$ & 20.2 & $3,279.2$ & $3,648.7$ & $3,962.3$ & $4,299.9$ & $4,660.7$ & $5,033.1$ \\
Foreign balance & $1,504.3$ & 11.4 & $1,898.6$ & $2,023.3$ & $2,135.4$ & $2,241.4$ & $2,347.4$ & $2,427.9$ \\
$\quad$ Exports & $4,560.6$ & 34.5 & $5,932.6$ & $6,326.9$ & $6,708.0$ & $7,107.0$ & $7,539.3$ & $7,965.2$ \\
$\quad$ Imports & $3,056.3$ & -23.2 & $4,034.0$ & $4,303.5$ & $4,572.6$ & $4,865.6$ & $5,191.9$ & $5,537.2$ \\
\hline
\end{tabular}

Table 8a: Macroeconomic projections (bln roubles)

\begin{tabular}{lrrrrrrrr}
\hline & 2013 & 2014 & 2015 & 2016 & 2017 & 2018 & 2019 & 2020 \\
\hline GDP & $26,031.2$ & $27,736.1$ & $29,645.5$ & $31,676.1$ & $33,831.6$ & $36,044.6$ & $38,356.8$ & $40,718.1$ \\
Private consumption & $13,805.3$ & $14,736.2$ & $15,761.6$ & $16,869.1$ & $18,071.0$ & $19,352.2$ & $20,720.7$ & $22,156.6$ \\
Government consumption & $4,309.3$ & $4,582.5$ & $4,892.1$ & $5,215.6$ & $5,550.3$ & $5,880.8$ & $6,218.8$ & $6,555.7$ \\
Gross fixed investment & $5,417.1$ & $5,893.3$ & $6,464.4$ & $7,090.4$ & $7,761.0$ & $8,439.2$ & $9,143.1$ & $9,855.9$ \\
Foreign balance & $2,499.5$ & $2,524.0$ & $2,527.4$ & $2,500.9$ & $2,449.2$ & $2,372.3$ & $2,274.3$ & $2,150.0$ \\
$\quad$ Exports & $8,402.4$ & $8,832.5$ & $9,293.8$ & $9,769.1$ & $10,263.3$ & $10,765.9$ & $11,286.4$ & $11,814.2$ \\
$\quad$ Imports & $5,902.9$ & $6,308.5$ & $6,766.3$ & $7,268.2$ & $7,814.0$ & $8,393.6$ & $9,012.2$ & $9,664.3$ \\
\hline
\end{tabular}


Table 8b: Macroeconomic projections: growth rates

\begin{tabular}{|c|c|c|c|c|c|c|c|c|}
\hline & $\begin{array}{r}2003 \\
\text { values } \\
\text { (bln. } \\
\text { Ruble) }\end{array}$ & $\begin{array}{r}\text { Share } \\
\text { in GDP (\%) }\end{array}$ & 2008 & 2009 & 2010 & 2011 & 2012 & 2013 \\
\hline GDP & $13,201.1$ & 100.0 & 7.87 & 6.83 & 6.78 & 6.88 & 6.46 & 6.34 \\
\hline Private consumption & $6,694.5$ & 50.7 & 6.79 & 6.46 & 6.53 & 6.84 & 6.55 & 6.61 \\
\hline Government consumption & $2,332.3$ & 17.7 & 8.41 & 6.82 & 6.67 & 6.57 & 6.17 & 5.93 \\
\hline Gross fixed investment & $2,669.9$ & 20.2 & 11.27 & 8.59 & 8.52 & 8.39 & 7.99 & 7.63 \\
\hline Foreign balance & $1,504.3$ & 11.4 & 6.57 & 5.54 & 4.96 & 4.73 & 3.43 & 2.95 \\
\hline Exports & $4,560.6$ & 34.5 & 6.65 & 6.02 & 5.95 & 6.08 & 5.65 & 5.49 \\
\hline Imports & $3,056.3$ & -23.2 & 6.68 & 6.25 & 6.41 & 6.71 & 6.65 & 6.60 \\
\hline
\end{tabular}

Table 8b: Macroeconomic projections: growth rates

\begin{tabular}{lccccccc}
\hline & $\mathbf{2 0 1 4}$ & $\mathbf{2 0 1 5}$ & $\mathbf{2 0 1 6}$ & $\mathbf{2 0 1 7}$ & $\mathbf{2 0 1 8}$ & $\mathbf{2 0 1 9}$ & $\mathbf{2 0 2 0}$ \\
\hline GDP & 6.55 & 6.88 & 6.85 & 6.80 & 6.54 & 6.41 & 6.16 \\
Private consumption & 6.74 & 6.96 & 7.03 & 7.12 & 7.09 & 7.07 & 6.93 \\
Government consumption & 6.34 & 6.75 & 6.61 & 6.42 & 5.95 & 5.75 & 5.42 \\
Gross fixed investment & 8.79 & 9.69 & 9.68 & 9.46 & 8.74 & 8.34 & 7.80 \\
Foreign balance & 0.98 & 0.13 & -1.05 & -2.07 & -3.14 & -4.13 & -5.47 \\
$\quad$ Exports & 5.12 & 5.22 & 5.11 & 5.06 & 4.90 & 4.84 & 4.68 \\
$\quad$ Imports & 6.87 & 7.26 & 7.42 & 7.51 & 7.42 & 7.37 & 7.24 \\
\hline
\end{tabular}

Table 9: CO2 emissions under the baseline scenario

\begin{tabular}{|c|c|c|c|c|c|c|c|}
\hline & 1990 & 2008 & 2009 & 2010 & 2011 & 2012 & 2013 \\
\hline Total CO2 emissions (Mt) & $2,138.7$ & $1,644.2$ & $1,680.3$ & $1,718.2$ & $1,765.5$ & $1,812.2$ & $1,857.7$ \\
\hline Total CO2 emissions (annual growth rate - \%) & & 1.95 & 2.19 & 2.26 & 2.76 & 2.64 & 2.51 \\
\hline $\mathrm{CO} 2$ emissions from the residential sector (Mt) & 182.1 & 148.8 & 149.8 & 150.9 & 153.6 & 155.3 & 156.9 \\
\hline $\begin{array}{l}\mathrm{CO} 2 \text { emissions from the residential sector } \\
\text { (annual growth rate - \%) }\end{array}$ & & 0.26 & 0.68 & 0.70 & 1.82 & 1.08 & 1.02 \\
\hline CO2 emissions by branches of activity (Mt) & $1,956.6$ & $1,495.3$ & $1,530.4$ & $1,567.3$ & $1,611.9$ & $1,656.9$ & $1,700.8$ \\
\hline $\begin{array}{l}\text { CO2 emissions by branches of activity (annual } \\
\text { growth rate - \%) }\end{array}$ & & 2.12 & 2.35 & 2.41 & 2.85 & 2.79 & 2.65 \\
\hline
\end{tabular}

Table 9: CO2 emissions under the baseline scenario

\begin{tabular}{|c|c|c|c|c|c|c|c|}
\hline & 2014 & 2015 & 2016 & 2017 & 2018 & 2019 & 2020 \\
\hline Total CO2 emissions (Mt) & $1,895.7$ & $1,932.9$ & $1,974.9$ & $2,017.7$ & $2,063.8$ & $2,109.0$ & $2,154.5$ \\
\hline Total CO2 emissions (annual growth rate - \%) & 2.05 & 1.96 & 2.17 & 2.17 & 2.28 & 2.19 & 2.15 \\
\hline $\mathrm{CO} 2$ emissions from the residential sector (Mt) & 157.7 & 158.0 & 158.6 & 159.1 & 159.7 & 160.1 & 160.1 \\
\hline $\begin{array}{l}\text { CO2 emissions from the residential sector } \\
\text { (annual growth rate - \%) }\end{array}$ & 0.49 & 0.22 & 0.35 & 0.32 & 0.41 & 0.22 & 0.03 \\
\hline CO2 emissions by branches of activity (Mt) & $1,738.1$ & $1,774.9$ & $1,816.3$ & $1,858.7$ & $1,904.1$ & $1,949.0$ & $1,994.4$ \\
\hline $\begin{array}{l}\text { CO2 emissions by branches of activity (annual } \\
\text { growth rate - \%) }\end{array}$ & 2.19 & 2.12 & 2.34 & 2.33 & 2.44 & 2.36 & 2.33 \\
\hline
\end{tabular}




\subsection{Three scenarios on energy efficiency and two policy scenarios}

Table 1 reports the evolution of real GDP under three different scenarios of energy efficiency growth, and two policy simulations. Whereas labour productivity is assumed to grow according to the 'innovative' projections under all four scenarios, reaching 260 percent growth between 2006 and 2020, the first three rows of table 1 report results on GDP growth for different assumptions regarding energy efficiency, as reported in section 3. The first scenario is once again the baseline scenario as shown in tables $8 \mathrm{a}$ and $8 \mathrm{~b}$, reported to facilitate a smooth comparison; the second scenario assumes a stronger improvement in energy intensity, of $60 \%$ over the period 2007-2020; and the third scenario assumes an improvement of just $30 \%$ over the same period.

The fourth and fifth row provide projections on policy simulations, assuming the introduction of a CO2 price of $22 \mathrm{EUR} / \mathrm{tCO} 2$, starting in 2015, which is in line with the PRIMES database. In order to simulate the adaptation that would in reality take place, when the introduction of $\mathrm{CO} 2$ pricing would be announced, the $\mathrm{CO} 2$ price is included gradually in the model, starting in 2012 and increasing linearly until the price of 22 EUR is reached in 2015. The fourth row applies this CO2 price to the initial baseline scenario with $43 \%$ energy efficiency gains, whereas the fifth row takes as basis the pessimistic scenario with just $30 \%$ of efficiency improvement. In the model, the revenues from pricing the $\mathrm{CO} 2$ emissions are recycled into firms' savings, simulating the current Emission Trading Scheme.

Table 1 shows the impact of energy efficiency as a driver of economic growth; whereas in the baseline, the average annual growth rate is $6.6 \%$, stronger gains in energy efficiency alone, up to $60 \%$, will stimulate economic growth by an additional 0.4 percentage point per year. On the other hand, when in the more pessimistic scenario the efficiency stays behind compared to the goals president Medvedev formulated, this will have a negative impact on economic growth of more than 0.3 percentage point per year on average. The gradual introduction of a CO2 price will decrease economic growth by slightly less than a percent for the first years, between 2012 and 2015, one year, but growth rates are projected to catch up quickly afterwards in both the scenarios to which it applies. The neutral scenario of $43 \%$ efficiency gains and a CO2 price leads a GDP level in 2020 that is very close to the more pessimistic scenario without intervention.

Having evaluated the economic impact of different paths of efficiency evolution, table 11 reports the projected evolution of $\mathrm{CO} 2$ emissions under all five scenarios. A comparison of the first three cases yields quite intuitive results. Under the baseline scenario, emissions grow by approximately $2.1 \%$ per year on average, whereas under the pessimistic scenario, emissions grow by 53\% between 2007 and 2020, which comes down to an annual growth rate of $3.3 \%$ on average. On the other hand, if Russia can realise a $60 \%$ improvement in efficiency in this period, this will lead to a slight decrease of emissions. Hence, the strong efficiency gain enables Russia to increase its GDP by a factor of 2.5 between 2007 and 2020, while emissions will not increase. 
Figure 4: GDP evolution under 3 energy efficiency scenarios with 2 policy simulations

GDP evolution (BIn. Ruble)

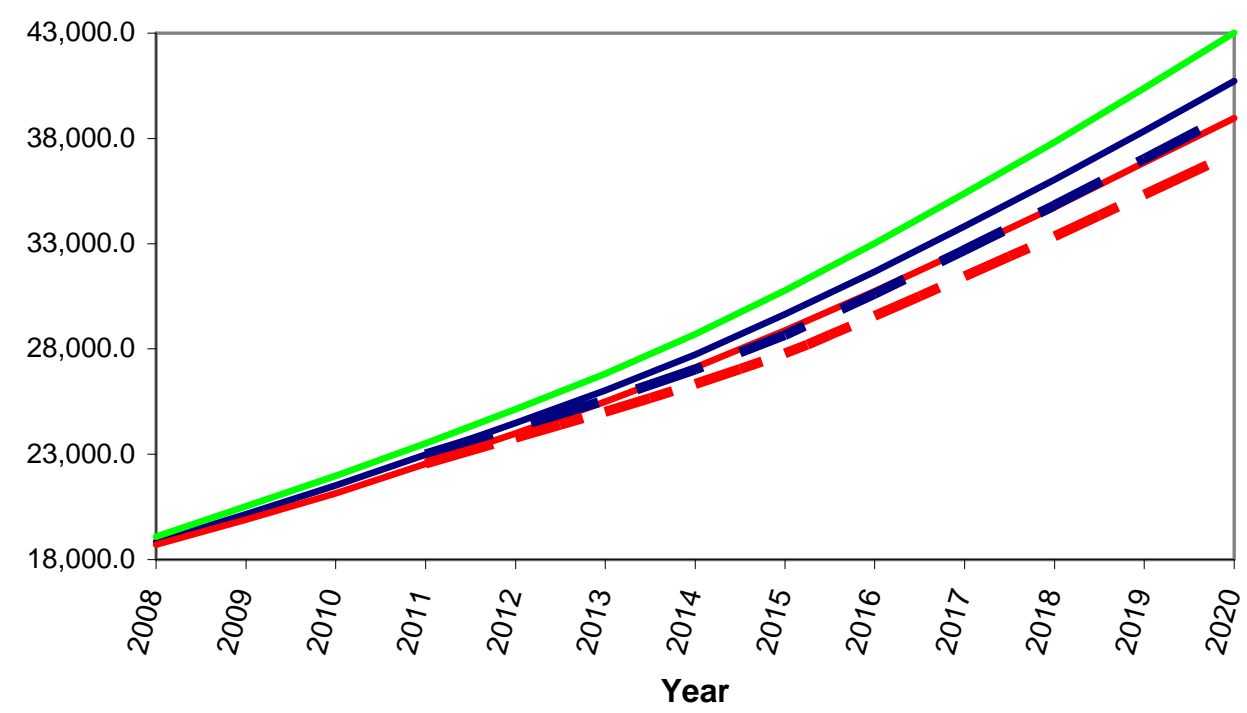

$\begin{array}{ll}\text { Baseline Scen. } & \text { Scen. } 30 \% \\ \text { Scen. } 60 \% & \text { Scen. } 43 \%+\text { CO2 price } \\ \text { Scen. } 30 \%+\text { CO2 price } & \end{array}$

Figure 5: Evolution of total CO2 emissions under 3 energy efficiency scenarios with 2 policy simulations

Total CO2 Emissions (MT of CO2)

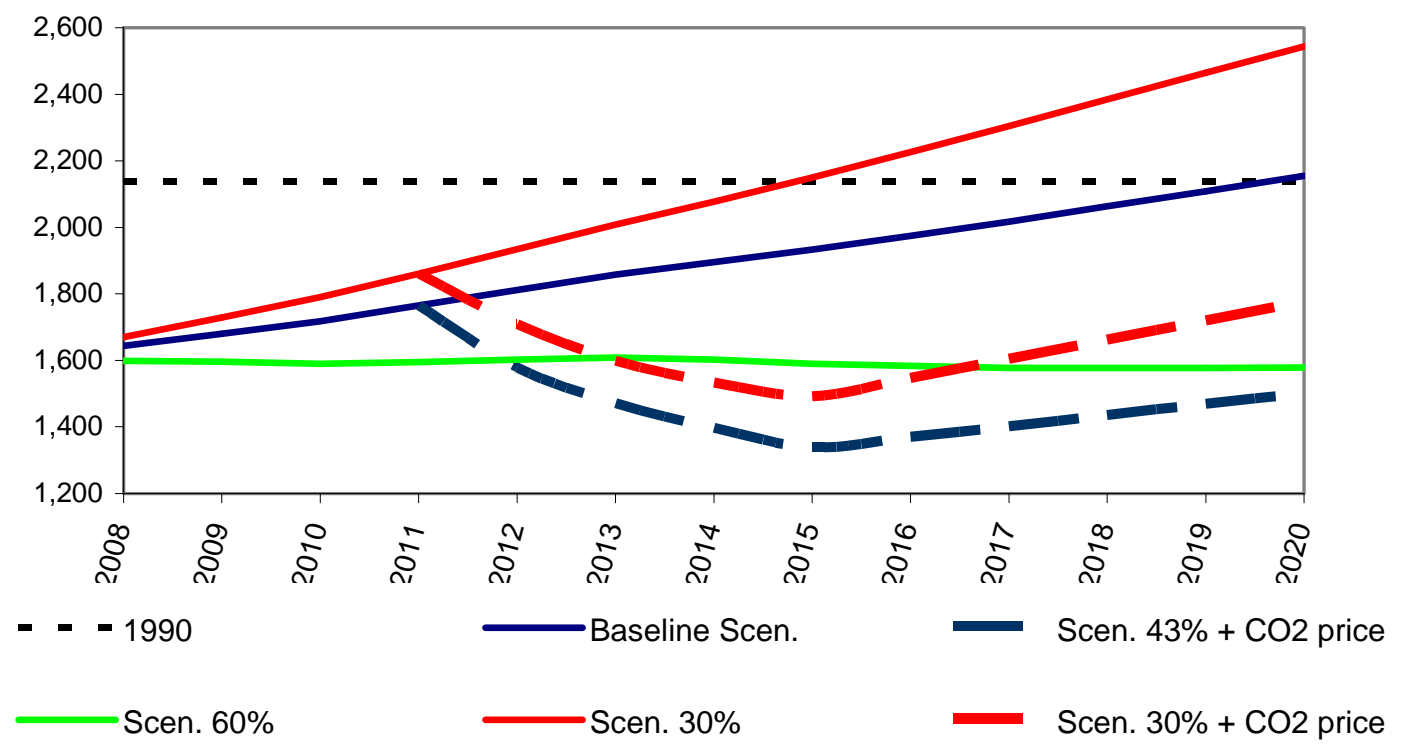


Table 10: 3 scenarios on energy efficiency and 2 policy simulations: GDP (in Bln.Rubles)

\begin{tabular}{|c|c|c|c|c|c|c|c|c|}
\hline & 2003 & 2007 & 2008 & 2009 & 2010 & 2011 & 2012 & 2013 \\
\hline - Baseli & $13,201.1$ & $17,481.4$ & $18,857.9$ & $20,146.5$ & $21,512.0$ & 22,992.5 & $24,478.3$ & $26,031.2$ \\
\hline - Scenario: $60 \%$ & $13,201.1$ & $17,481.4$ & $19,090.0$ & $20,535.7$ & $21,985.0$ & $23,526.0$ & $25,141.9$ & 26,827.3 \\
\hline - Scenario: $30 \%$ & 13,201.1 & $17,481.4$ & $18,714.2$ & $19,895.1$ & 21,153.9 & $22,545.6$ & 23,995.1 & $25,500.9$ \\
\hline - Scenario: $43 \%$ + CO2 price & $13,201.1$ & $17,481.4$ & $18,857.9$ & $20,146.5$ & $21,512.0$ & $22,992.5$ & $24,266.8$ & $25,562.2$ \\
\hline - Scenario: $30 \%+\mathrm{CO} 2$ price & $13,201.1$ & $17,481.4$ & $18,714.2$ & $19,895.1$ & $21,153.9$ & $22,545.6$ & $23,775.2$ & $25,001.8$ \\
\hline
\end{tabular}

Table 10: 3 scenarios on energy efficiency and 2 policy simulations: GDP (in Bln.Rubles)

\begin{tabular}{lrrrrrrr}
\hline & $\mathbf{2 0 1 4}$ & $\mathbf{2 0 1 5}$ & $\mathbf{2 0 1 6}$ & $\mathbf{2 0 1 7}$ & $\mathbf{2 0 1 8}$ & $\mathbf{2 0 1 9}$ & $\mathbf{2 0 2 0}$ \\
\hline - Baseline Scenario & $27,736.1$ & $29,645.5$ & $31,676.1$ & $33,831.6$ & $36,044.6$ & $38,356.8$ & $40,718.1$ \\
- Scenario: 60\% & $28,692.0$ & $30,785.7$ & $33,014.6$ & $35,385.8$ & $37,827.0$ & $40,385.8$ & $43,011.0$ \\
- Scenario: 30\% & $27,108.4$ & $28,870.4$ & $30,741.2$ & $32,718.9$ & $34,740.9$ & $36,839.6$ & $38,967.1$ \\
- Scenario: 43\% + CO2 price & $27,017.4$ & $28,653.7$ & $30,612.7$ & $32,688.0$ & $34,807.3$ & $37,010.6$ & $39,239.3$ \\
- Scenario: 30\% + CO2 price & $26,332.5$ & $27,784.3$ & $29,566.3$ & $31,445.1$ & $33,353.7$ & $35,322.0$ & $37,295.0$ \\
\hline
\end{tabular}

Table 11: 3 scenarios on energy efficiency and 2 policy simulations: CO2 emissions (MT)

\begin{tabular}{lrrrrrrrr}
\hline & $\mathbf{1 9 9 0}$ & $\mathbf{2 0 0 7}$ & $\mathbf{2 0 0 8}$ & $\mathbf{2 0 0 9}$ & $\mathbf{2 0 1 0}$ & $\mathbf{2 0 1 1}$ & $\mathbf{2 0 1 2}$ & $\mathbf{2 0 1 3}$ \\
\hline CO2 emissions (MT) & & & & & & & & \\
- Baseline Scenario & $2,138.7$ & $1,612.8$ & $1,644.2$ & $1,680.3$ & $1,718.2$ & $1,765.5$ & $1,812.2$ & $1,857.7$ \\
- Scenario: $60 \%$ & $2,138.7$ & $1,612.8$ & $1,598.7$ & $1,596.0$ & $1,590.3$ & $1,595.4$ & $1,602.9$ & $1,608.7$ \\
- Scenario: 30\% & $2,138.7$ & $1,612.8$ & $1,670.3$ & $1,728.8$ & $1,790.1$ & $1,860.8$ & $1,934.4$ & $2,008.2$ \\
- Scenario: $43 \%+$ CO2 price & $2,138.7$ & $1,612.8$ & $1,644.2$ & $1,680.3$ & $1,718.2$ & $1,765.5$ & $1,578.7$ & $1,470.7$ \\
- Scenario: 30\% + CO2 price & $2,138.7$ & $1,612.8$ & $1,670.3$ & $1,728.8$ & $1,790.1$ & $1,860.8$ & $1,708.4$ & $1,599.1$ \\
\hline
\end{tabular}

Table 11: 3 scenarios on energy efficiency and 2 policy simulations: CO2 emissions (MT)

\begin{tabular}{lcccccccc}
\hline & $\mathbf{2 0 1 4}$ & $\mathbf{2 0 1 5}$ & $\mathbf{2 0 1 6}$ & $\mathbf{2 0 1 7}$ & $\mathbf{2 0 1 8}$ & $\mathbf{2 0 1 9}$ & $\mathbf{2 0 2 0}$ & $\begin{array}{c}\mathbf{2 0 2 0} \\
(\mathbf{\% 1 9 9 0})\end{array}$ \\
\hline CO2 emissions (MT) & & & & & & & & \\
- Baseline Scenario & $1,895.7$ & $1,932.9$ & $1,974.9$ & $2,017.7$ & $2,063.8$ & $2,109.0$ & $2,154.5$ & $100.7 \%$ \\
- Scenario: $60 \%$ & $1,602.2$ & $1,590.1$ & $1,583.6$ & $1,577.8$ & $1,577.7$ & $1,577.0$ & $1,577.9$ & $73.8 \%$ \\
- Scenario: $30 \%$ & $2,077.9$ & $2,149.6$ & $2,226.0$ & $2,304.2$ & $2,384.1$ & $2,464.0$ & $2,543.6$ & $118.9 \%$ \\
- Scenario: 43\% + CO2 price & $1,396.8$ & $1,339.5$ & $1,370.1$ & $1,401.9$ & $1,436.2$ & $1,469.1$ & $1,500.2$ & $70.1 \%$ \\
- Scenario: 30\% + CO2 price & $1,533.5$ & $1,491.9$ & $1,547.2$ & $1,604.3$ & $1,662.9$ & $1,720.8$ & $1,776.4$ & $83.1 \%$ \\
\hline
\end{tabular}

The last column of table 11 expresses the projected emissions in 2020 as a percentage of emissions in 1990, which is the reference year under the Kyoto protocol. Under the baseline scenario, emissions will be slightly larger than in 1990; if energy efficiency gains stay behind, the 1990 level will be exceeded by close to $19 \%$. However, in the fourth and fifth rows of the table, the strong effect of the introduction of a CO2 price becomes clear: whereas until 2012, the emissions grow at the same pace as under the initial $43 \%$ and $30 \%$ scenarios, in the last nine years a significant gain can be made, that is gradually reached between 2012 and 2015, when the emission price is fully applied and equal to its assumed value of 22 euros per KT of CO2. Thanks to this improvement, overall emissions are projected to reach a level that is close to $30 \%$ smaller than the level in 1990 when efficiency grows by $43 \%$, and $16 \%$ smaller when it grows by $30 \%$, whereas 
in both cases emissions are 30\% smaller than under the same scenario without the introduction of a $\mathrm{CO} 2$ price. Figures 4 and 5 present these projections graphically, and together show the existing trade-off between persistent economic over the entire sample and a significant reduction of $\mathrm{CO} 2$ emissions by introduction of a $\mathrm{CO} 2$ price.

\subsection{Three scenarios of economic growth and energy efficiency}

The results that were presented in the previous section were all obtained under the assumption that labour productivity, as driver of economic growth, followed a fixed path, increasing by a factor 2.6 over the period 2006-2020. In this section, this assumption will be loosened, and the impact of lower growth rates will be analysed. In the three official long run scenarios for Russia that were developed by its government, the scenario that is identified as baseline in this study, in line with the projections made by the European Commission, is in fact the most optimistic scenario. Therefore, in this section this optimistic scenario will be compared to a neutral and pessimistic scenario, with growth factors of 2.4 and 2.0, respectively.

The positive impact of energy efficiency gains on economic growth was exhibited in the previous section. In figure 4, the size of this effect is gently visible. In the reverse direction, a similar effect exists, where one can interpret economic growth as a stimulus for energy efficiency investments and resulting gains. While various argumentations can be brought up to explain this effect, that is commonly observed in many developing economies or countries in transition (e.g. cost advantages as a result of a decrease in energy consumption, attempts to fight externalities from energy consumption, increasing economic and political independence, etc.), in this study it is particularly relevant to evaluate its consequences; if economic growth stays behind, energy efficiency gains might respond accordingly. Particularly since labour productivity is used as driver of economic development, the linkages between economic growth and efficiency gains are strong; both depend heavily on technological improvements. For this reason, in this section the two evolutions are coupled and together evaluated in three scenarios:

- Optimistic scenario:

o Labour productivity: $+260 \%$ between $2006-2020$

o Energy efficiency: $+60 \%$ between 2007-2020.

- Neutral scenario:

o Labour productivity: $+240 \%$ between $2006-2020$

o Energy efficiency: + 43\% between 2007-2020.

- Pessimistic scenario:

o Labour productivity: $+200 \%$ between $2006-2020$

o Energy efficiency: + 30\% between 2007-2020.

Tables 12 and 13 provide the results for the three scenarios, comparing them based on GDP growth and CO2 emissions. In these tables, the effect of a coupled evolution of productivity and efficiency is clearly illustrated. Tables 16-19 in the appendix provide 
sector-specific projections on the evolution of emissions over time and an insight in the contribution of the industries as a whole and the residential sector. On the aggregate level, under the optimistic scenario, GDP is multiplied by a factor 2.5 between 20072020 , whereas the pessimistic scenario yields an increase of just $85 \%$. On an annual basis, GDP growth rates fluctuate around $7 \%$ in the main part of the sample in the optimistic case, while in the pessimistic scenario, they start at $6 \%$ and decline to $4.3 \%$. On top of that, emissions are significantly lower under the optimistic scenario, despite the considerably larger growth rate, and evolve to a level well below the 1990 level. On the other hand, under the pessimistic scenario they come closest to the level in 1990, even when economic growth is low, due to a lack of efficiency gains.

Table 12: Three scenarios of economic growth and energy efficiency: GDP

\begin{tabular}{crrrrrrrr}
\hline & 2003 & 2007 & $\mathbf{2 0 0 8}$ & $\mathbf{2 0 0 9}$ & $\mathbf{2 0 1 0}$ & $\mathbf{2 0 1 1}$ & $\mathbf{2 0 1 2}$ & $\mathbf{2 0 1 3}$ \\
\hline - Optimistic scenario & & & & & & & & \\
GDP (Bln. Rubles) & $13,201.1$ & $17,481.4$ & $19,090.0$ & $20,535.7$ & $21,985.0$ & $23,526.0$ & $25,141.9$ & $26,827.3$ \\
GDP growth (\%) & & 8.10 & 9.20 & 7.57 & 7.06 & 7.01 & 6.87 & 6.70 \\
- $\quad$ Neutral scenario & & & & & & & & \\
GDP (Bln. Rubles) & $13,201.1$ & $17,481.4$ & $18,800.3$ & $20,019.7$ & $21,296.2$ & $22,663.7$ & $24,027.3$ & $25,444.7$ \\
GDP growth (\%) & & 8.10 & 7.54 & 6.49 & 6.38 & 6.42 & 6.02 & 5.90 \\
- Pessimistic scenario & & & & & & & & \\
GDP (Bln. Rubles) & $13,201.1$ & $17,481.4$ & $18,523.9$ & $19,479.3$ & $20,449.1$ & $21,485.9$ & $22,533.1$ & $23,576.4$ \\
GDP growth (\%) & & 8.10 & 5.96 & 5.16 & 4.98 & 5.07 & 4.87 & 4.63 \\
\hline
\end{tabular}

Table 12: Three scenarios of economic growth and energy efficiency: GDP

\begin{tabular}{crrrrrrr}
\hline & $\mathbf{2 0 1 4}$ & $\mathbf{2 0 1 5}$ & $\mathbf{2 0 1 6}$ & $\mathbf{2 0 1 7}$ & $\mathbf{2 0 1 8}$ & $\mathbf{2 0 1 9}$ & $\mathbf{2 0 2 0}$ \\
\hline - Optimistic scenario & & & & & & & \\
GDP (Bln. Rubles) & $28,692.0$ & $30,785.7$ & $33,014.6$ & $35,385.8$ & $37,827.0$ & $40,385.8$ & $43,011.0$ \\
GDP growth (\%) & 6.95 & 7.30 & 7.24 & 7.18 & 6.90 & 6.76 & 6.50 \\
- $\quad$ Neutral scenario & & & & & & & \\
GDP (Bln. Rubles) & $27,000.0$ & $28,713.2$ & $30,517.6$ & $32,422.5$ & $34,372.4$ & $36,405.2$ & $38,486.7$ \\
GDP growth (\%) & 6.11 & 6.35 & 6.28 & 6.24 & 6.01 & 5.91 & 5.72 \\
- Pessimistic scenario & & & & & & & \\
GDP (Bln. Rubles) & $24,715.8$ & $25,934.5$ & $27,170.7$ & $28,429.7$ & $29,698.5$ & $30,999.7$ & $32,320.5$ \\
GDP growth (\%) & 4.83 & 4.93 & 4.77 & 4.63 & 4.46 & 4.38 & 4.26 \\
\hline
\end{tabular}

Table 13: Three scenarios of economic growth and energy efficiency: CO2 emissions

\begin{tabular}{lrrrrrrrr}
\hline & $\mathbf{1 9 9 0}$ & $\mathbf{2 0 0 3}$ & $\mathbf{2 0 0 7}$ & $\mathbf{2 0 0 8}$ & $\mathbf{2 0 0 9}$ & $\mathbf{2 0 1 0}$ & $\mathbf{2 0 1 1}$ & $\mathbf{2 0 1 2}$ \\
\hline - Optimistic scenario & $2,138.7$ & $1,484.0$ & $1,612.8$ & $1,598.7$ & $1,596.0$ & $1,590.3$ & $1,595.4$ & $1,602.9$ \\
- Neutral scenario & $2,138.7$ & $1,484.0$ & $1,612.8$ & $1,638.1$ & $1,667.8$ & $1,698.2$ & $1,737.0$ & $1,774.8$ \\
- Pessimistic scenario & $2,138.7$ & $1,484.0$ & $1,612.8$ & $1,649.3$ & $1,685.7$ & $1,720.9$ & $1,762.0$ & $1,803.6$ \\
\hline
\end{tabular}

Table 13: Three scenarios of economic growth and energy efficiency: CO2 emissions

\begin{tabular}{lrrrrrrrr}
\hline & $\mathbf{2 0 1 3}$ & $\mathbf{2 0 1 4}$ & $\mathbf{2 0 1 5}$ & $\mathbf{2 0 1 6}$ & $\mathbf{2 0 1 7}$ & $\mathbf{2 0 1 8}$ & $\mathbf{2 0 1 9}$ & $\mathbf{2 0 2 0}$ \\
\hline - Optimistic scenario & $1,608.7$ & $1,602.2$ & $1,590.1$ & $1,583.6$ & $1,577.8$ & $1,577.7$ & $1,577.0$ & $1,577.9$ \\
- Neutral scenario & $1,811.5$ & $1,841.2$ & $1,867.7$ & $1,898.2$ & $1,929.3$ & $1,964.0$ & $1,998.1$ & $2,033.2$ \\
- Pessimistic scenario & $1,842.6$ & $1,879.9$ & $1,915.7$ & $1,952.5$ & $1,987.5$ & $2,024.6$ & $2,061.4$ & $2,099.3$ \\
\hline
\end{tabular}


Nevertheless, it is remarkable that under all three scenarios, the total CO2 emissions in 2020 are lower than they were in 1990. When comparing these results to the three energy efficiency scenarios presented in the previous subsection, it is indicative that only when labour productivity grows strongly and energy efficiency stays behind, CO2 emissions clearly exceed their levels in 1990. The baseline scenario leads emissions to hit this level by 2020, and under all other scenarios - i.e. when energy efficiency gains are stronger or economic growth smaller - they will be considerably smaller than in 1990 .

\section{CONCLUSIONS}

This study has provided a set of results on CO2 emissions in Russia between up to 2020, under various scenarios of economic development and several paths of improvements considering energy efficiency. An interpretation of these results can be used for drawing instructive conclusions on realistic paths of evolution of both economic growth and emissions, and on requirements and potentials for Russia in attempts to reduce or control emissions over the next decade.

First, the projections provide an indication for credible goals to be set in post-Kyoto negotiations; even when facing strong and persistent economic growth, emissions can be controlled to stay below their benchmark level. This is an encouraging message, when compared to the considerable challenges that exist at the global level to cut back emissions, using 1990 as a reference year. However, at the same time it raises the question whether 1990 is the proper benchmark to be applied, especially given the particular circumstances in Russia, where the economic downturn and turmoil in the 1990s led to a sharp reduction of CO2 emissions; in 2003, the base year of this study, emissions reached a level smaller than $70 \%$ of the amount in 1990 .

Second, the results emphasise the importance of accomplishing strong energy efficiency gains, and their effect on the economy and on emissions of greenhouse gases. Efficiency improvements were identified as a strong driver of economic growth. Besides, they play a crucial role in reducing the effects of persistent GDP growth as it is foreseen in most projections on the Russian economy. For this goal, the targets as they were articulated by president Medvedev in a recent decree seem to be effective and capable to control emissions under the most optimistic growth scenario. However, results also show that emissions can be expected to grow at a much higher rate when the efficiency improvements are not realised or when they stay behind compared to the $40 \%$ goal as it was set by the president. In other words, given the high expectations of economic growth for Russia over the next 14 years, a strong commitment is required to stimulate structural changes in the economy that will realise an efficiency gain of $40 \%$.

Finally, next to the active stimulation of a strong reduction of energy intensity, the introduction of a $\mathrm{CO} 2$ price as a policy instrument can have a strong structural impact on the emissions, which comes at the expense of a decline in economic growth that is of a 
much more temporary nature. Although particular details of such a measure will be likely to influence the effect to a considerable extent, the reasonable choice in this study of a price that is in line with current standards proves to lead to very promising results, with emissions that are reduced by $30 \%$. The set of results provided in this study can play a guiding role as well when considering alternative configurations for cap-and-trade instruments. 


\section{APPENDIX}

Table 14: CO2 emissions under the baseline scenario by branch of activity (in kt)

\begin{tabular}{|c|c|c|c|c|c|c|c|c|c|c|c|c|c|c|c|}
\hline & 1990 & 2003 & 2008 & 2009 & 2010 & 2011 & 2012 & 2013 & 2014 & 2015 & 2016 & 2017 & 2018 & 2019 & 2020 \\
\hline Electricity & $1,158,030$ & 865,650 & 954,082 & 977,492 & $1,001,941$ & $1,027,432$ & $1,052,755$ & $1,077,458$ & $1,100,134$ & $1,123,267$ & $1,150,655$ & $1,179,573$ & $1,211,798$ & $1,245,180$ & $1,281,104$ \\
\hline Crude oil & 10,762 & 16,019 & 18,346 & 19,406 & 20,449 & 21,669 & 22,472 & 22,934 & 22,133 & 21,118 & 19,840 & 18,319 & 16,576 & 14,667 & 12,620 \\
\hline Refined petroleum and other fuels & 23,076 & 26,947 & 32,012 & 32,436 & 32,909 & 33,902 & 35,147 & 36,205 & 36,248 & 36,026 & 35,645 & 35,031 & 34,199 & 32,996 & 31,359 \\
\hline Natural gas & 10,762 & 16,019 & 17,485 & 18,125 & 18,783 & 19,454 & 19,871 & 20,292 & 20,756 & 21,225 & 21,787 & 22,375 & 23,023 & 23,669 & 24,341 \\
\hline Coal & 1,620 & 1,536 & 1,790 & 1,831 & 1,879 & 1,921 & 1,994 & 2,071 & 2,153 & 2,241 & 2,345 & 2,459 & 2,587 & 2,726 & 2,879 \\
\hline Ferrous metallurgy & 137,980 & 90,860 & 96,354 & 98,925 & 101,781 & 105,193 & 109,208 & 113,249 & 117,329 & 121,579 & 126,294 & 131,201 & 136,377 & 141,570 & 146,801 \\
\hline Nonferrous metallurgy & 14,340 & 32,040 & 32,203 & 32,633 & 33,122 & 33,933 & 34,739 & 35,549 & 36,237 & 36,875 & 37,614 & 38,370 & 39,202 & 40,004 & 40,792 \\
\hline Chemical and petrochemical industry & 24,970 & 26,900 & 29,793 & 30,301 & 30,821 & 31,917 & 32,967 & 33,968 & 34,663 & 35,211 & 35,682 & 36,012 & 36,218 & 36,203 & 35,914 \\
\hline Machinery & 11,020 & 6,070 & 6,556 & 6,746 & 6,938 & 7,184 & 7,382 & 7,563 & 7,746 & 7,934 & 8,137 & 8,325 & 8,497 & 8,637 & 8,748 \\
\hline Lumber, pulp and paper industry & 5,310 & 2,100 & 2,337 & 2,360 & 2,387 & 2,462 & 2,536 & 2,608 & 2,656 & 2,694 & 2,730 & 2,757 & 2,777 & 2,781 & 2,767 \\
\hline Construction materials & 12,655 & 1,395 & 1,472 & 1,496 & 1,524 & 1,570 & 1,621 & 1,670 & 1,717 & 1,767 & 1,822 & 1,876 & 1,928 & 1,973 & 2,008 \\
\hline Light industry & 240 & 190 & 238 & 243 & 248 & 256 & 263 & 269 & 275 & 279 & 284 & 289 & 295 & 300 & 305 \\
\hline Food processing industry & 15,190 & 5,190 & 5,680 & 5,721 & 5,768 & 5,893 & 6,027 & 6,164 & 6,257 & 6,325 & 6,402 & 6,477 & 6,564 & 6,641 & 6,707 \\
\hline Other industries & 15,640 & 5,990 & 6,697 & 6,785 & 6,877 & 7,070 & 7,273 & 7,479 & 7,637 & 7,775 & 7,917 & 8,053 & 8,191 & 8,309 & 8,400 \\
\hline Construction & 12,655 & 1,395 & 1,497 & 1,545 & 1,598 & 1,663 & 1,728 & 1,792 & 1,865 & 1,947 & 2,038 & 2,131 & 2,223 & 2,311 & 2,393 \\
\hline Agriculture and forestry & 48,500 & 15,980 & 19,490 & 19,709 & 19,954 & 20,520 & 21,180 & 21,872 & 22,410 & 22,878 & 23,381 & 23,892 & 24,459 & 25,002 & 25,495 \\
\hline Transport and communication & 272,970 & 193,460 & 225,660 & 230,198 & 234,995 & 243,408 & 252,153 & 260,878 & 267,922 & 274,601 & 281,341 & 287,804 & 294,057 & 299,560 & 303,938 \\
\hline Trade, brokerage and catering & 49,675 & 5,040 & 5,662 & 5,745 & 5,837 & 5,978 & 6,104 & 6,234 & 6,341 & 6,433 & 6,546 & 6,667 & 6,810 & 6,952 & 7,097 \\
\hline Housing, R\&D and other services & 81,500 & 28,370 & 32,630 & 33,232 & 33,852 & 34,695 & 35,607 & 36,545 & 37,487 & 38,465 & 39,529 & 40,627 & 41,780 & 42,950 & 44,124 \\
\hline Government and financial services & 49,675 & 5,040 & 5,362 & 5,484 & 5,606 & 5,770 & 5,901 & 6,020 & 6,122 & 6,219 & 6,321 & 6,412 & 6,495 & 6,559 & 6,605 \\
\hline Total (kt) & $1,956,570$ & $1,346,190$ & $1,495,346$ & $1,530,415$ & $1,567,268$ & $1,611,889$ & $1,656,928$ & $1,700,818$ & $1,738,086$ & $1,774,859$ & $1,816,309$ & $1,858,650$ & $1,904,055$ & $1,948,990$ & $1,994,397$ \\
\hline
\end{tabular}


Table 15: CO2 emission growth rates under the baseline scenario per branch of activity (in \%)

\begin{tabular}{|c|c|c|c|c|c|c|c|c|c|c|c|c|c|c|}
\hline & $\begin{array}{l}\text { Initial Values: } \\
1990 \\
\text { (in kt) }\end{array}$ & 2008 & 2009 & 2010 & 2011 & 2012 & 2013 & 2014 & 2015 & 2016 & 2017 & 2018 & 2019 & 2020 \\
\hline Electricity & $1,158,030$ & 2.18 & 2.45 & 2.50 & 2.54 & 2.46 & 2.35 & 2.10 & 2.10 & 2.44 & 2.51 & 2.73 & 2.75 & 2.89 \\
\hline Crude oil & 10,762 & 6.90 & 5.78 & 5.37 & 5.96 & 3.71 & 2.05 & -3.49 & -4.59 & -6.05 & -7.67 & -9.51 & -11.52 & -13.96 \\
\hline Refined petroleum and other fuels & 23,076 & 0.38 & 1.33 & 1.46 & 3.02 & 3.67 & 3.01 & 0.12 & -0.61 & -1.06 & -1.72 & -2.38 & -3.52 & -4.96 \\
\hline Natural gas & 10,762 & 3.65 & 3.66 & 3.63 & 3.57 & 2.15 & 2.12 & 2.29 & 2.26 & 2.65 & 2.70 & 2.90 & 2.81 & 2.84 \\
\hline Coal & 1,620 & 1.48 & 2.29 & 2.58 & 2.27 & 3.78 & 3.84 & 3.96 & 4.12 & 4.63 & 4.86 & 5.22 & 5.37 & 5.60 \\
\hline Ferrous metallurgy & 137,980 & 2.25 & 2.67 & 2.89 & 3.35 & 3.82 & 3.70 & 3.60 & 3.62 & 3.88 & 3.89 & 3.94 & 3.81 & 3.69 \\
\hline Nonferrous metallurgy & 14,340 & 0.68 & 1.33 & 1.50 & 2.45 & 2.38 & 2.33 & 1.93 & 1.76 & 2.00 & 2.01 & 2.17 & 2.05 & 1.97 \\
\hline Chemical and petrochemical industry & 24,970 & 1.66 & 1.70 & 1.72 & 3.56 & 3.29 & 3.04 & 2.05 & 1.58 & 1.34 & 0.93 & 0.57 & -0.04 & -0.80 \\
\hline Machinery & 11,020 & 3.45 & 2.89 & 2.85 & 3.54 & 2.76 & 2.45 & 2.41 & 2.43 & 2.55 & 2.31 & 2.06 & 1.66 & 1.28 \\
\hline Lumber, pulp and paper industry & 5,310 & 0.67 & 1.00 & 1.13 & 3.13 & 3.02 & 2.82 & 1.86 & 1.44 & 1.32 & 0.99 & 0.73 & 0.16 & -0.51 \\
\hline Construction materials & 12,655 & 1.82 & 1.64 & 1.83 & 3.02 & 3.23 & 3.05 & 2.84 & 2.91 & 3.10 & 2.96 & 2.76 & 2.32 & 1.82 \\
\hline Light industry & 240 & 1.43 & 2.11 & 2.17 & 3.22 & 2.56 & 2.47 & 1.94 & 1.62 & 1.84 & 1.79 & 1.95 & 1.76 & 1.63 \\
\hline Food processing industry & 15,190 & -0.04 & 0.73 & 0.81 & 2.17 & 2.28 & 2.28 & 1.50 & 1.09 & 1.22 & 1.16 & 1.34 & 1.17 & 1.00 \\
\hline Other industries & 15,640 & 0.94 & 1.31 & 1.36 & 2.79 & 2.88 & 2.82 & 2.12 & 1.80 & 1.83 & 1.71 & 1.71 & 1.44 & 1.10 \\
\hline Construction & 12,655 & 4.01 & 3.26 & 3.38 & 4.07 & 3.94 & 3.71 & 4.03 & 4.41 & 4.68 & 4.58 & 4.32 & 3.95 & 3.54 \\
\hline Agriculture and forestry & 48,500 & 0.39 & 1.12 & 1.24 & 2.84 & 3.22 & 3.27 & 2.46 & 2.09 & 2.19 & 2.19 & 2.37 & 2.22 & 1.97 \\
\hline Transport and communication & 272,970 & 2.06 & 2.01 & 2.08 & 3.58 & 3.59 & 3.46 & 2.70 & 2.49 & 2.45 & 2.30 & 2.17 & 1.87 & 1.46 \\
\hline Trade, brokerage and catering & 49,675 & 0.52 & 1.47 & 1.60 & 2.42 & 2.10 & 2.14 & 1.72 & 1.45 & 1.76 & 1.84 & 2.14 & 2.08 & 2.09 \\
\hline Housing, R\&D and other services & 81,500 & 2.10 & 1.84 & 1.87 & 2.49 & 2.63 & 2.64 & 2.58 & 2.61 & 2.77 & 2.78 & 2.84 & 2.80 & 2.73 \\
\hline Government and financial services & 49,675 & 2.54 & 2.28 & 2.21 & 2.93 & 2.27 & 2.02 & 1.70 & 1.58 & 1.65 & 1.44 & 1.29 & 0.98 & 0.69 \\
\hline Total (kt) & $1,956,570$ & 2.12 & 2.35 & 2.41 & 2.85 & 2.79 & 2.65 & 2.19 & 2.12 & 2.34 & 2.33 & 2.44 & 2.36 & 2.33 \\
\hline
\end{tabular}


Table 16a: CO2 emissions under the optimistic scenario

\begin{tabular}{|c|c|c|c|c|c|c|c|c|c|c|c|c|c|c|c|}
\hline & 1990 & 2003 & 2008 & 2009 & 2010 & 2011 & 2012 & 2013 & 2014 & 2015 & 2016 & 2017 & 2018 & 2019 & 2020 \\
\hline Total CO2 emissions (Mt) & $2,138.7$ & $1,484.0$ & $1,598.7$ & $1,596.0$ & $1,590.3$ & $1,595.4$ & $1,602.9$ & $1,608.7$ & $1,602.2$ & $1,590.1$ & $1,583.6$ & $1,577.8$ & $1,577.7$ & $1,577.0$ & $1,577.9$ \\
\hline Total CO2 emissions (annual growth rate - \%) & & & 1.57 & 1.81 & 1.82 & 2.28 & 2.17 & 2.07 & 1.64 & 1.44 & 1.63 & 1.64 & 1.80 & 1.74 & 1.76 \\
\hline $\mathrm{CO} 2$ emissions from the residential sector $(\mathrm{Mt})$ & 182.1 & 137.8 & 146.8 & 145.6 & 142.8 & 141.5 & 140.6 & 139.6 & 137.6 & 135.1 & 133.0 & 131.1 & 129.7 & 128.2 & 126.7 \\
\hline $\mathrm{CO} 2$ emissions from the residential sector (annual growth rate - \%) & & & 0.24 & 0.56 & 0.51 & 1.50 & 0.78 & 0.73 & 0.23 & -0.10 & 0.03 & 0.02 & 0.18 & 0.09 & 0.05 \\
\hline $\mathrm{CO} 2$ emissions by branches of activity $(\mathrm{Mt})$ & $1,956.6$ & $1,346.2$ & $1,451.9$ & $1,450.4$ & $1,447.5$ & $1,453.8$ & $1,462.3$ & $1,469.1$ & $1,464.5$ & $1,455.0$ & $1,450.6$ & $1,446.7$ & $1,448.0$ & $1,448.9$ & $1,451.2$ \\
\hline $\mathrm{CO} 2$ emissions by branches of activity (annual growth rate - \%) & & & 1.70 & 1.94 & 1.95 & 2.36 & 2.31 & 2.19 & 1.77 & 1.58 & 1.78 & 1.78 & 1.94 & 1.88 & 1.90 \\
\hline
\end{tabular}

Table 16b: CO2 emissions under the neutral scenario

\begin{tabular}{|c|c|c|c|c|c|c|c|c|c|c|c|c|c|c|c|}
\hline & 1990 & 2003 & 2008 & 2009 & 2010 & 2011 & 2012 & 2013 & 2014 & 2015 & 2016 & 2017 & 2018 & 2019 & 2020 \\
\hline Total CO2 emissions (Mt) & $2,138.7$ & $1,484.0$ & $1,638.1$ & $1,667.8$ & $1,698.2$ & $1,737.0$ & $1,774.8$ & $1,811.5$ & $1,841.2$ & $1,867.7$ & $1,898.2$ & $1,929.3$ & $1,964.0$ & 1,998.1 & $2,033.2$ \\
\hline Total CO2 emissions (annual growth rate - \%) & & & 2.26 & 2.21 & 2.08 & 2.39 & 2.36 & 2.16 & 2.02 & 1.91 & 1.92 & 1.80 & 1.87 & 1.82 & 1.84 \\
\hline $\mathrm{CO} 2$ emissions from the residential sector (Mt) & 182.1 & 137.8 & 148.8 & 149.7 & 150.4 & 152.7 & 153.9 & 155.0 & 155.3 & 155.2 & 155.2 & 155.3 & 155.5 & 155.7 & 155.8 \\
\hline $\mathrm{CO} 2$ emissions from the residential sector (annual growth rate - \%) & & & 0.91 & 0.98 & 0.78 & 1.71 & 1.47 & 1.24 & 0.90 & 0.50 & 0.36 & 0.23 & 0.28 & 0.22 & 0.23 \\
\hline CO2 emissions by branches of activity (Mt) & $1,956.6$ & $1,346.2$ & $1,489.3$ & 1,518.1 & 1,547.8 & $1,584.3$ & $1,620.9$ & $1,656.5$ & $1,685.9$ & $1,712.5$ & $1,743.0$ & $1,774.0$ & $1,808.4$ & $1,842.4$ & $1,877.5$ \\
\hline $\mathrm{CO} 2$ emissions by branches of activity (annual growth rate - \%) & & & 2.40 & 2.33 & 2.21 & 2.45 & 2.45 & 2.25 & 2.13 & 2.04 & 2.06 & 1.94 & 2.01 & 1.96 & 1.97 \\
\hline
\end{tabular}

Table 16c: CO2 emissions under the pessimistic scenario

\begin{tabular}{|c|c|c|c|c|c|c|c|c|c|c|c|c|c|c|c|}
\hline & 1990 & 2003 & 2008 & 2009 & 2010 & 2011 & 2012 & 2013 & 2014 & 2015 & 2016 & 2017 & 2018 & 2019 & 2020 \\
\hline Total CO2 emissions (Mt) & $2,138.7$ & $1,484.0$ & $1,649.3$ & $1,685.7$ & $1,720.9$ & $1,762.0$ & $1,803.6$ & $1,842.6$ & $1,879.9$ & $1,915.7$ & $1,952.5$ & $1,987.5$ & $2,024.6$ & $2,061.4$ & $2,099.3$ \\
\hline Total CO2 emissions (annual growth rate - \%) & & & 1.57 & 1.81 & 1.82 & 2.28 & 2.17 & 2.07 & 1.64 & 1.44 & 1.63 & 1.64 & 1.80 & 1.74 & 1.76 \\
\hline $\mathrm{CO} 2$ emissions from the residential sector $(\mathrm{Mt})$ & 182.1 & 137.8 & 149.8 & 151.3 & 152.5 & 155.1 & 157.3 & 159.3 & 160.7 & 161.5 & 162.1 & 162.5 & 162.9 & 163.3 & 163.7 \\
\hline $\mathrm{CO} 2$ emissions from the residential sector (annual growth rate - \%) & & & 0.24 & 0.56 & 0.51 & 1.50 & 0.78 & 0.73 & 0.23 & -0.10 & 0.03 & 0.02 & 0.18 & 0.09 & 0.05 \\
\hline $\mathrm{CO} 2$ emissions by branches of activity (Mt) & $1,956.6$ & $1,346.2$ & $1,499.5$ & $1,534.5$ & $1,568.4$ & $1,606.9$ & $1,646.3$ & $1,683.3$ & $1,719.1$ & $1,754.2$ & $1,790.4$ & $1,825.0$ & $1,861.7$ & $1,898.1$ & $1,935.6$ \\
\hline $\mathrm{CO} 2$ emissions by branches of activity (annual growth rate - \%) & & & 1.70 & 1.94 & 1.95 & 2.36 & 2.31 & 2.19 & 1.77 & 1.58 & 1.78 & 1.78 & 1.94 & 1.88 & 1.90 \\
\hline
\end{tabular}


Table 17: CO2 emissions under the optimistic scenario by branch of activity (in kt)

\begin{tabular}{|c|c|c|c|c|c|c|c|c|c|c|c|c|c|c|c|c|}
\hline & 1990 & 2003 & 2007 & 2008 & 2009 & 2010 & 2011 & 2012 & 2013 & 2014 & 2015 & 2016 & 2017 & 2018 & 2019 & $202 C$ \\
\hline Electricity & $1,158,030$ & 865,650 & 933,694 & 923,239 & 921,341 & 917,623 & 916,402 & 916,722 & 916,536 & 910,751 & 902,203 & 898,136 & 895,273 & 897,130 & 899,989 & 906,026 \\
\hline Crude oil & 10,762 & 16,019 & 17,161 & 18,763 & 20,024 & 20,765 & 21,573 & 22,324 & 22,637 & 21,791 & 20,735 & 19,417 & 17,848 & 16,044 & 14,040 & 11,845 \\
\hline Refined petroleum and other fuels & 23,076 & 26,947 & 31,891 & 31,233 & 31,120 & 31,295 & 32,040 & 32,820 & 33,347 & 32,912 & 32,180 & 31,302 & 30,203 & 28,919 & 27,277 & 25,187 \\
\hline Natural gas & 10,762 & 16,019 & 16,870 & 17,102 & 17,324 & 17,172 & 17,014 & 16,895 & 16,798 & 16,664 & 16,471 & 16,387 & 16,334 & 16,389 & 16,461 & 16,600 \\
\hline Coal & 1,620 & 1,536 & 1,764 & 1,700 & 1,678 & 1,690 & 1,706 & 1,728 & 1,752 & 1,772 & 1,791 & 1,821 & 1,857 & 1,905 & 1,960 & 2,02 \\
\hline Ferrous metallurgy & 137,980 & 90,860 & 94,233 & 93,193 & 93,348 & 94,284 & 95,909 & 97,660 & 99,374 & 100,717 & 101,865 & 103,431 & 105,077 & 107,061 & 108,993 & 110,98 \\
\hline Nonferrous metallurgy & 14,340 & 32,040 & 31,986 & 31,238 & 30,901 & 30,542 & 30,530 & 30,594 & 30,670 & 30,543 & 30,302 & 30,197 & 30,124 & 30,193 & 30,250 & $30,33 c$ \\
\hline $\begin{array}{l}\text { Chemical and petrochemical } \\
\text { industry }\end{array}$ & 24,970 & 26,900 & 29,306 & 29,301 & 29,332 & 29,292 & 29,786 & 30,292 & 30,718 & 30,787 & 30,664 & 30,512 & 30,260 & 29,974 & 29,516 & 28,843 \\
\hline Machinery & 11,020 & 6,070 & 6,338 & 6,380 & 6,418 & 6,396 & 6,425 & 6,454 & 6,473 & 6,470 & 6,455 & 6,463 & 6,467 & 6,480 & 6,477 & 6,466 \\
\hline Lumber, pulp and paper industry & 5,310 & 2,100 & 2,322 & 2,281 & 2,257 & 2,233 & 2,256 & 2,282 & 2,304 & 2,300 & 2,282 & 2,267 & 2,246 & 2,225 & 2,193 & $2,14 \pi$ \\
\hline Construction materials & 12,655 & 1,395 & 1,446 & 1,416 & 1,395 & 1,382 & 1,390 & 1,400 & 1,407 & 1,408 & 1,408 & 1,413 & 1,417 & 1,422 & 1,423 & 1,417 \\
\hline Light industry & 240 & 190 & 235 & 232 & 233 & 231 & 231 & 232 & 233 & 233 & 231 & 230 & 230 & 231 & 232 & 233 \\
\hline Food processing industry & 15,190 & 5,190 & 5,682 & 5,496 & 5,392 & 5,293 & 5,280 & 5,283 & 5,291 & 5,246 & 5,172 & 5,116 & 5,064 & 5,038 & 5,008 & 4,976 \\
\hline Other industries & 15,640 & 5,990 & 6,635 & 6,512 & 6,444 & 6,385 & 6,428 & 6,484 & 6,536 & 6,529 & 6,492 & 6,468 & 6,441 & 6,431 & 6,407 & 6,365 \\
\hline Construction & 12,655 & 1,395 & 1,439 & 1,449 & 1,455 & 1,465 & 1,488 & 1,511 & 1,531 & 1,552 & 1,576 & 1,606 & 1,637 & 1,667 & 1,693 & 1,715 \\
\hline Agriculture and forestry & 48,500 & 15,980 & 19,414 & 18,939 & 18,719 & 18,586 & 18,781 & 19,030 & 19,286 & 19,354 & 19,324 & 19,343 & 19,375 & 19,483 & 19,567 & 19,611 \\
\hline Transport and communication & 272,970 & 193,460 & 221,106 & 220,948 & 220,826 & 220,997 & 224,658 & 228,567 & 232,037 & 233,365 & 233,846 & 234,495 & 234,846 & 235,310 & 235,096 & 234,006 \\
\hline Trade, brokerage and catering & 49,675 & 5,040 & 5,632 & 5,503 & 5,453 & 5,371 & 5,342 & 5,331 & 5,329 & 5,290 & 5,227 & 5,193 & 5,172 & 5,184 & 5,202 & 5,232 \\
\hline Housing, R\&D and other services & 81,500 & 28,370 & 31,960 & 31,721 & 31,486 & 31,319 & 31,414 & 31,546 & 31,671 & 31,695 & 31,667 & 31,728 & 31,803 & 31,957 & 32,114 & $32,28 \varepsilon$ \\
\hline Government and financial services & 49,675 & 5,040 & 5,229 & 5,227 & 5,230 & 5,188 & 5,189 & 5,192 & 5,187 & 5,152 & 5,102 & 5,068 & 5,030 & 5,003 & 4,968 & $4,92 \mathrm{~s}$ \\
\hline Total (kt) & $1,956,570$ & $1,346,190$ & $1,464,342$ & $1,451,875$ & $1,450,374$ & $1,447,510$ & $1,453,843$ & $1,462,348$ & $1,469,118$ & $1,464,530$ & $1,454,992$ & $1,450,592$ & $1,446,702$ & $1,448,047$ & $1,448,866$ & $1,451,226$ \\
\hline
\end{tabular}


Table 18: CO2 emissions under the neutral scenario by branch of activity (in kt)

\begin{tabular}{|c|c|c|c|c|c|c|c|c|c|c|c|c|c|c|c|c|}
\hline & 1990 & 2003 & 2007 & 2008 & 2009 & 2010 & 2011 & 2012 & 2013 & 2014 & 2015 & 2016 & 2017 & 2018 & 2019 & 2020 \\
\hline Electricity & $1,158,030$ & 865,650 & 933,694 & 949,684 & 968,750 & 988,232 & $1,008,272$ & $1,028,038$ & $1,046,800$ & $1,063,048$ & $1,078,849$ & $1,098,029$ & $1,118,298$ & $1,141,567$ & $1,165,356$ & $1,190,874$ \\
\hline Crude oil & 10,762 & 16,019 & 17,161 & 18,333 & 19,348 & 20,325 & 21,441 & 22,173 & 22,855 & 22,644 & 21,881 & 20,897 & 19,710 & 18,335 & 16,819 & 15,184 \\
\hline $\begin{array}{l}\text { Refined petroleum and other } \\
\text { fuels }\end{array}$ & 23,076 & 26,947 & 31,891 & 31,988 & 32,366 & 32,763 & 33,668 & 34,773 & 35,864 & 36,193 & 36,022 & 35,729 & 35,266 & 34,679 & 33,868 & 32,828 \\
\hline Natural gas & 10,762 & 16,019 & 16,870 & 17,416 & 17,974 & 18,533 & 19,076 & 19,388 & 19,677 & 19,975 & 20,294 & 20,694 & 21,116 & 21,600 & 22,081 & 22,583 \\
\hline Coal & 1,620 & 1,536 & 1,764 & 1,779 & 1,810 & 1,847 & 1,879 & 1,938 & 1,998 & 2,059 & 2,125 & 2,203 & 2,287 & 2,383 & 2,485 & 2,596 \\
\hline Ferrous metallurgy & 137,980 & 90,860 & 94,233 & 95,872 & 97,969 & 100,276 & 103,099 & 106,445 & 109,729 & 112,966 & 116,312 & 120,036 & 123,920 & 128,079 & 132,263 & 136,526 \\
\hline Nonferrous metallurgy & 14,340 & 32,040 & 31,986 & 32,123 & 32,473 & 32,872 & 33,574 & 34,269 & 34,962 & 35,531 & 36,035 & 36,633 & 37,256 & 37,975 & 38,688 & 39,424 \\
\hline $\begin{array}{l}\text { Chemical and petrochemical } \\
\text { industry }\end{array}$ & 24,970 & 26,900 & 29,306 & 29,738 & 30,187 & 30,636 & 31,642 & 32,596 & 33,539 & 34,247 & 34,762 & 35,222 & 35,586 & 35,891 & 36,067 & 36,111 \\
\hline Machinery & 11,020 & 6,070 & 6,338 & 6,506 & 6,647 & 6,788 & 6,975 & 7,122 & 7,249 & 7,376 & 7,510 & 7,658 & 7,798 & 7,932 & 8,046 & 8,142 \\
\hline $\begin{array}{l}\text { Lumber, pulp and paper } \\
\text { industry }\end{array}$ & 5,310 & 2,100 & 2,322 & 2,331 & 2,348 & 2,368 & 2,434 & 2,498 & 2,562 & 2,608 & 2,641 & 2,671 & 2,697 & 2,720 & 2,734 & 2,740 \\
\hline Construction materials & 12,655 & 1,395 & 1,446 & 1,460 & 1,472 & 1,486 & 1,517 & 1,552 & 1,585 & 1,617 & 1,649 & 1,686 & 1,722 & 1,758 & 1,790 & 1,818 \\
\hline Light industry & 240 & 190 & 235 & 238 & 242 & 247 & 254 & 260 & 266 & 270 & 274 & 278 & 282 & 287 & 292 & 296 \\
\hline Food processing industry & 15,190 & 5,190 & 5,682 & 5,675 & 5,712 & 5,752 & 5,868 & 5,990 & 6,117 & 6,202 & 6,258 & 6,322 & 6,385 & 6,465 & 6,541 & 6,620 \\
\hline Other industries & 15,640 & 5,990 & 6,635 & 6,684 & 6,757 & 6,832 & 7,002 & 7,180 & 7,361 & 7,501 & 7,611 & 7,725 & 7,836 & 7,955 & 8,066 & 8,171 \\
\hline Construction & 12,655 & 1,395 & 1,439 & 1,481 & 1,513 & 1,546 & 1,590 & 1,634 & 1,674 & 1,721 & 1,776 & 1,838 & 1,901 & 1,964 & 2,024 & 2,081 \\
\hline Agriculture and forestry & 48,500 & 15,980 & 19,414 & 19,484 & 19,692 & 19,916 & 20,446 & 21,047 & 21,678 & 22,170 & 22,554 & 22,964 & 23,381 & 23,860 & 24,341 & 24,830 \\
\hline Transport and communication & 272,970 & 193,460 & 221,106 & 224,994 & 228,787 & 232,668 & 239,952 & 247,448 & 255,071 & 261,387 & 266,808 & 272,262 & 277,536 & 282,862 & 287,849 & 292,459 \\
\hline Trade, brokerage and catering & 49,675 & 5,040 & 5,632 & 5,657 & 5,731 & 5,810 & 5,931 & 6,035 & 6,141 & 6,220 & 6,283 & 6,365 & 6,453 & 6,565 & 6,678 & 6,799 \\
\hline $\begin{array}{l}\text { Housing, R\&D and other } \\
\text { services }\end{array}$ & 81,500 & 28,370 & 31,960 & 32,476 & 32,930 & 33,384 & 34,045 & 34,765 & 35,488 & 36,197 & 36,907 & 37,680 & 38,475 & 39,326 & 40,194 & 41,087 \\
\hline $\begin{array}{l}\text { Government and financial } \\
\text { services }\end{array}$ & 49,675 & 5,040 & 5,229 & 5,334 & 5,430 & 5,523 & 5,655 & 5,757 & 5,849 & 5,925 & 5,995 & 6,070 & 6,138 & 6,206 & 6,262 & 6,309 \\
\hline Total (kt) & $1,956,570$ & $1,346,190$ & $1,464,342$ & $1,489,253$ & $1,518,139$ & $1,547,802$ & $1,584,320$ & $1,620,911$ & $1,656,464$ & $1,685,857$ & $1,712,547$ & $1,742,961$ & $1,774,044$ & $1,808,410$ & $1,842,445$ & $1,877,477$ \\
\hline
\end{tabular}


Table 19: CO2 emissions under the pessimistic scenario by branch of activity (in kt)

\begin{tabular}{|c|c|c|c|c|c|c|c|c|c|c|c|c|c|c|c|c|}
\hline & 1990 & 2003 & 2007 & 2008 & 2009 & 2010 & 2011 & 2012 & 2013 & 2014 & 2015 & 2016 & 2017 & 2018 & 2019 & 2020 \\
\hline Electricity & $1,158,030$ & 865,650 & 933,694 & 956,894 & 979,999 & $1,002,363$ & $1,023,711$ & $1,046,093$ & $1,066,961$ & $1,087,270$ & $1,107,090$ & $1,127,724$ & $1,148,844$ & $1,171,841$ & $1,194,866$ & $1,218,753$ \\
\hline Crude oil & 10,762 & 16,019 & 17,161 & 18,070 & 18,853 & 19,573 & 20,447 & 21,216 & 21,900 & 22,560 & 23,123 & 23,567 & 23,341 & 22,907 & 22,404 & 21,845 \\
\hline $\begin{array}{l}\text { Refined petroleum and other } \\
\text { fuels }\end{array}$ & 23,076 & 26,947 & 31,891 & 32,391 & 32,992 & 33,533 & 34,484 & 35,417 & 36,291 & 37,026 & 37,704 & 38,404 & 38,590 & 38,648 & 38,632 & 38,566 \\
\hline Natural gas & 10,762 & 16,019 & 16,870 & 17,463 & 18,033 & 18,585 & 19,119 & 19,651 & 20,147 & 20,635 & 21,059 & 21,455 & 21,918 & 22,439 & 22,960 & 23,502 \\
\hline Coal & 1,620 & 1,536 & 1,764 & 1,805 & 1,852 & 1,901 & 1,939 & 1,985 & 2,030 & 2,076 & 2,129 & 2,191 & 2,259 & 2,334 & 2,411 & 2,491 \\
\hline Ferrous metallurgy & 137,980 & 90,860 & 94,233 & 96,499 & 98,849 & 101,238 & 103,909 & 106,756 & 109,515 & 112,325 & 115,316 & 118,558 & 121,978 & 125,634 & 129,352 & 133,188 \\
\hline Nonferrous metallurgy & 14,340 & 32,040 & 31,986 & 32,488 & 33,091 & 33,707 & 34,581 & 35,488 & 36,377 & 37,213 & 38,001 & 38,826 & 39,665 & 40,583 & 41,517 & 42,497 \\
\hline industry & 24,970 & 26,900 & 29,306 & 29,864 & 30,414 & 30,945 & 32,028 & 33,084 & 34,093 & 35,052 & 35,953 & 36,842 & 37,589 & 38,302 & 38,970 & 39,615 \\
\hline Machinery & 11,020 & 6,070 & 6,338 & 6,484 & 6,593 & 6,692 & 6,834 & 6,978 & 7,100 & 7,234 & 7,370 & 7,499 & 7,633 & 7,771 & 7,899 & 8,023 \\
\hline $\begin{array}{l}\text { Lumber, pulp and paper } \\
\text { industry }\end{array}$ & 5,310 & 2,100 & 2,322 & 2,348 & 2,378 & 2,406 & 2,479 & 2,550 & 2,617 & 2,680 & 2,738 & 2,797 & 2,846 & 2,894 & 2,939 & 2,983 \\
\hline Construction materials & 12,655 & 1,395 & 1,446 & 1,462 & 1,472 & 1,481 & 1,503 & 1,526 & 1,544 & 1,564 & 1,587 & 1,612 & 1,636 & 1,662 & 1,685 & 1,708 \\
\hline Light industry & 240 & 190 & 235 & 240 & 246 & 252 & 260 & 268 & 276 & 283 & 289 & 294 & 300 & 305 & 311 & 316 \\
\hline Food processing industry & 15,190 & 5,190 & 5,682 & 5,772 & 5,884 & 5,994 & 6,171 & 6,349 & 6,523 & 6,676 & 6,811 & 6,951 & 7,078 & 7,215 & 7,350 & 7,491 \\
\hline Other industries & 15,640 & 5,990 & 6,635 & 6,758 & 6,890 & 7,015 & 7,226 & 7,434 & 7,631 & 7,811 & 7,978 & 8,148 & 8,301 & 8,457 & 8,610 & 8,765 \\
\hline Construction & 12,655 & 1,395 & 1,439 & 1,469 & 1,486 & 1,499 & 1,519 & 1,539 & 1,553 & 1,572 & 1,597 & 1,623 & 1,653 & 1,683 & 1,712 & 1,738 \\
\hline Agriculture and forestry & 48,500 & 15,980 & 19,414 & 19,787 & 20,233 & 20,666 & 21,363 & 22,051 & 22,722 & 23,312 & 23,846 & 24,398 & 24,886 & 25,389 & 25,888 & 26,401 \\
\hline $\begin{array}{l}\text { Transport and } \\
\text { communication } \\
\text { Trade, brokerage and }\end{array}$ & 272,970 & 193,460 & 221,106 & 226,008 & 230,681 & 235,245 & 242,968 & 250,500 & 257,630 & 264,553 & 271,361 & 278,282 & 284,388 & 290,460 & 296,458 & 302,508 \\
\hline $\begin{array}{l}\text { catering } \\
\text { Housing, R\&D and other }\end{array}$ & 49,675 & 5,040 & 5,632 & 5,738 & 5,866 & 5,990 & 6,144 & 6,298 & 6,446 & 6,572 & 6,676 & 6,781 & 6,888 & 7,008 & 7,128 & 7,254 \\
\hline $\begin{array}{l}\text { services } \\
\text { Government and financial }\end{array}$ & 81,500 & 28,370 & 31,960 & 32,624 & 33,219 & 33,802 & 34,553 & 35,309 & 36,008 & 36,711 & 37,429 & 38,175 & 38,926 & 39,714 & 40,508 & 41,323 \\
\hline services & 49,675 & 5,040 & 5,229 & 5,345 & 5,444 & 5,535 & 5,664 & 5,792 & 5,906 & 6,019 & 6,126 & 6,228 & 6,326 & 6,427 & 6,522 & 6,615 \\
\hline Total (kt) & $1,956,570$ & $1,346,190$ & $1,464,342$ & $1,499,509$ & $1,534,475$ & $1,568,423$ & $1,606,905$ & $1,646,284$ & $1,683,271$ & $1,719,143$ & $1,754,183$ & $1,790,356$ & $1,825,047$ & $1,861,673$ & $1,898,121$ & $1,935,583$ \\
\hline
\end{tabular}




\section{CESifo Working Paper Series}

for full list see www.cesifo-group.org/wp

(address: Poschingerstr. 5, 81679 Munich, Germany, office@cesifo.de)

2909 Rolf Golombek, Mads Greaker and Michael Hoel, Climate Policy without Commitment, January 2010

2910 Sascha O. Becker and Ludger Woessmann, The Effect of Protestantism on Education before the Industrialization: Evidence from 1816 Prussia, January 2010

2911 Michael Berlemann, Marco Oestmann and Marcel Thum, Demographic Change and Bank Profitability. Empirical Evidence from German Savings Banks, January 2010

2912 Øystein Foros, Hans Jarle Kind and Greg Shaffer, Mergers and Partial Ownership, January 2010

2913 Sean Holly, M. Hashem Pesaran and Takashi Yamagata, Spatial and Temporal Diffusion of House Prices in the UK, January 2010

2914 Christian Keuschnigg and Evelyn Ribi, Profit Taxation and Finance Constraints, January 2010

2915 Hendrik Vrijburg and Ruud A. de Mooij, Enhanced Cooperation in an Asymmetric Model of Tax Competition, January 2010

2916 Volker Meier and Martin Werding, Ageing and the Welfare State: Securing Sustainability, January 2010

2917 Thushyanthan Baskaran and Zohal Hessami, Globalization, Redistribution, and the Composition of Public Education Expenditures, January 2010

2918 Angel de la Fuente, Testing, not Modelling, the Impact of Cohesion Support: A Theoretical Framework and some Preliminary Results for the Spanish Regions, January 2010

2919 Bruno S. Frey and Paolo Pamini, World Heritage: Where Are We? An Empirical Analysis, January 2010

2920 Susanne Ek and Bertil Holmlund, Family Job Search, Wage Bargaining, and Optimal Unemployment Insurance, January 2010

2921 Mariagiovanna Baccara, Allan Collard-Wexler, Leonardo Felli and Leeat Yariv, Gender and Racial Biases: Evidence from Child Adoption, January 2010

2922 Kurt R. Brekke, Roberto Cellini, Luigi Siciliani and Odd Rune Straume, Competition and Quality in Regulated Markets with Sluggish Demand, January 2010

2923 Stefan Bauernschuster, Oliver Falck and Niels Große, Can Competition Spoil Reciprocity? - A Laboratory Experiment, January 2010 
2924 Jerome L. Stein, A Critique of the Literature on the US Financial Debt Crisis, January 2010

2925 Erkki Koskela and Jan König, Profit Sharing, Wage Formation and Flexible Outsourcing under Labor Market Imperfection, January 2010

2926 Gabriella Legrenzi and Costas Milas, Spend-and-Tax Adjustments and the Sustainability of the Government’s Intertemporal Budget Constraint, January 2010

2927 Piero Gottardi, Jean Marc Tallon and Paolo Ghirardato, Flexible Contracts, January 2010

2928 Gebhard Kirchgässner and Jürgen Wolters, The Role of Monetary Aggregates in the Policy Analysis of the Swiss National Bank, January 2010

2929 J. Trent Alexander, Michael Davern and Betsey Stevenson, Inaccurate Age and Sex Data in the Census PUMS Files: Evidence and Implications, January 2010

2930 Stefan Krasa and Mattias K. Polborn, Competition between Specialized Candidates, January 2010

2931 Yin-Wong Cheung and Xingwang Qian, Capital Flight: China’s Experience, January 2010

2932 Thomas Hemmelgarn and Gaetan Nicodeme, The 2008 Financial Crisis and Taxation Policy, January 2010

2933 Marco Faravelli, Oliver Kirchkamp and Helmut Rainer, Social Welfare versus Inequality Concerns in an Incomplete Contract Experiment, January 2010

2934 Mohamed El Hedi Arouri and Christophe Rault, Oil Prices and Stock Markets: What Drives what in the Gulf Corporation Council Countries?, January 2010

2935 Wolfgang Lechthaler, Christian Merkl and Dennis J. Snower, Monetary Persistence and the Labor Market: A New Perspective, January 2010

2936 Klaus Abberger and Wolfgang Nierhaus, Markov-Switching and the Ifo Business Climate: The Ifo Business Cycle Traffic Lights, January 2010

2937 Mark Armstrong and Steffen Huck, Behavioral Economics as Applied to Firms: A Primer, February 2010

2938 Guglielmo Maria Caporale and Alessandro Girardi, Price Formation on the EuroMTS Platform, February 2010

2939 Hans Gersbach, Democratic Provision of Divisible Public Goods, February 2010

2940 Adam Isen and Betsey Stevenson, Women’s Education and Family Behavior: Trends in Marriage, Divorce and Fertility, February 2010 
2941 Peter Debaere, Holger Görg and Horst Raff, Greasing the Wheels of International Commerce: How Services Facilitate Firms’ International Sourcing, February 2010

2942 Emanuele Forlani, Competition in the Service Sector and the Performances of Manufacturing Firms: Does Liberalization Matter?, February 2010

2943 James M. Malcomson, Do Managers with Limited Liability Take More Risky Decisions? An Information Acquisition Model, February 2010

2944 Florian Englmaier and Steve Leider, Gift Exchange in the Lab - It is not (only) how much you give ..., February 2010

2945 Andrea Bassanini and Giorgio Brunello, Barriers to Entry, Deregulation and Workplace Training: A Theoretical Model with Evidence from Europe, February 2010

2946 Jan-Emmanuel De Neve, James H. Fowler and Bruno S. Frey, Genes, Economics, and Happiness, February 2010

2947 Camille Cornand and Frank Heinemann, Measuring Agents' Reaction to Private and Public Information in Games with Strategic Complementarities, February 2010

2948 Roel Beetsma and Massimo Giuliodori, Discretionary Fiscal Policy: Review and Estimates for the EU, February 2010

2949 Agnieszka Markiewicz, Monetary Policy, Model Uncertainty and Exchange Rate Volatility, February 2010

2950 Hans Dewachter and Leonardo Iania, An Extended Macro-Finance Model with Financial Factors, February 2010

2951 Helmuth Cremer, Philippe De Donder and Pierre Pestieau, Education and Social Mobility, February 2010

2952 Zuzana Brixiová and Balázs Égert, Modeling Institutions, Start-Ups and Productivity during Transition, February 2010

2953 Roland Strausz, The Political Economy of Regulatory Risk, February 2010

2954 Sanjay Jain, Sumon Majumdar and Sharun W. Mukand, Workers without Borders? Culture, Migration and the Political Limits to Globalization, February 2010

2955 Andreas Irmen, Steady-State Growth and the Elasticity of Substitution, February 2010

2956 Bengt-Arne Wickström, The Optimal Babel - An Economic Framework for the Analysis of Dynamic Language Rights, February 2010

2957 Stefan Bauernschuster and Helmut Rainer, From Politics to the Family: How Sex-Role Attitudes Keep on Diverging in Reunified Germany, February 2010 
2958 Patricia Funk and Christina Gathmann, How do Electoral Systems Affect Fiscal Policy? Evidence from State and Local Governments, 1890 to 2005, February 2010

2959 Betsey Stevenson, Beyond the Classroom: Using Title IX to Measure the Return to High School Sports, February 2010

2960 R. Quentin Grafton, Tom Kompas and Ngo Van Long, Biofuels Subsidies and the Green Paradox, February 2010

2961 Oliver Falck, Stephan Heblich, Alfred Lameli and Jens Suedekum, Dialects, Cultural Identity, and Economic Exchange, February 2010

2962 Bård Harstad, The Dynamics of Climate Agreements, February 2010

2963 Frederick van der Ploeg and Cees Withagen, Is There Really a Green Paradox?, February 2010

2964 Ingo Vogelsang, Incentive Regulation, Investments and Technological Change, February 2010

2965 Jan C. van Ours and Lenny Stoeldraijer, Age, Wage and Productivity, February 2010

2966 Michael Hoel, Climate Change and Carbon Tax Expectations, February 2010

2967 Tommaso Nannicini and Roberto Ricciuti, Autocratic Transitions and Growth, February 2010

2968 Sebastian Brauer and Frank Westermann, A Note on the Time Series Measure of Conservatism, February 2010

2969 Wolfram F. Richter, Efficient Education Policy - A Second-Order Elasticity Rule, February 2010

2970 Tomer Blumkin, Yoram Margalioth and Efraim Sadka, Taxing Children: The Redistributive Role of Child Benefits - Revisited, February 2010

2971 Chang Woon Nam and Georg Wamser, Application of Regionally Varying Additionality Degrees in the Practice of EU Cohesion Policy, February 2010

2972 Ali Bayar, Frédéric Dramais, Cristina Mohora, Masudi Opese and Bram Smeets, Modeling Russia for Climate Change Issues, February 2010 